\title{
The Role of Landscape Design in Cultural Rural Areas. A Didactic Exercise to Experiment a Research-by-Design Process Applied to an Italian UNESCO Wine Site
}

\author{
Catherine Dezio ${ }^{1, *}$, Can Zhang ${ }^{2}$, Yilan Zhang ${ }^{2}$ and Davide Marino ${ }^{3}$ \\ 1 Department of Architecture and Urban Studies, Politecnico di Milano, 20133 Milano, Italy \\ 2 Independent Researcher, 20133 Milano, Italy; can.zhang@mail.polimi.it (C.Z.); \\ yilan.zhang@mail.polimi.it (Y.Z.) \\ 3 Department of Bioscience and Territory, Università degli Studi del Molise, 86090 Pesche, Italy; \\ dmarino@unimol.it \\ * Correspondence: catherine.dezio@polimi.it
}

Citation: Dezio, C.; Zhang, C.;

Zhang, Y.; Marino, D. The Role of

Landscape Design in Cultural Rural Areas. A Didactic Exercise to Experiment a Research-by-Design Process Applied to an Italian UNESCO Wine Site. Architecture 2021, 1,117-139. https://doi.org/10.3390/ architecture1020010

Received: 17 August 2021

Accepted: 15 November 2021

Published: 22 November 2021

Publisher's Note: MDPI stays neutral with regard to jurisdictional claims in published maps and institutional affiliations.

Copyright: (c) 2021 by the authors. Licensee MDPI, Basel, Switzerland. This article is an open access article distributed under the terms and conditions of the Creative Commons Attribution (CC BY) license (https:// creativecommons.org/licenses/by/ $4.0 /)$.

\begin{abstract}
Rural landscapes all over the world are subject to great transformations, first being the continuous and slow depopulation of towns and villages. It is a dramatic phenomenon that causes devastating consequences for environmental systems and for the tangible and intangible heritage of entire territories. The situation becomes more ambiguous when it comes to cultural landscapes, especially those internationally recognized as exceptional (i.e., inscribed on the UNESCO (The United Nations Educational, Scientific and Cultural Organization) World Heritage List). In this case, the risk is to abandon agricultural production in favor of consumerist tourist economies, which can damage the territorial authenticity. In this paper, we question the role of the landscape design in strengthening territorial resilience. In particular, a composite and interdependent action has been proposed between landscape design and implementation of a multifunctional agriculture model, oriented towards tourism. To undertake this investigation, a master's thesis work on Landscape Architecture has been examined as an opportunity to test the research-by-design method through the didactic process. The application case is the Italian UNESCO site of Vignale Monferrato, a depopulated rural village, characterized by abandoned land and buildings. The paper concludes by outlining replicability application scenarios for the proposed model.
\end{abstract}

Keywords: cultural rural landscape; research-by-design; didactic process

\section{Introduction}

In 1992, the World Heritage Committee decided to define a separate category in the World Heritage List that recognizes cultural landscapes [1]. The definition of cultural landscape was born much earlier, when, during the twentieth century, various landscape scholars (geographers, urban planners, sociologists) recognized, in some rural territories, a harmonious balance in the relationship between environmental systems and the anthropogenic components, thanks to which the territories remain as such, while adapting to the transformations [2-8]. It is for this characteristic of adaptation to the events that they are often taken into consideration as resilient systems [7-15]. In particular, Barbera et al. have seen prototypes of resilient socio-ecological systems in traditional agricultural landscapes, tracing an evaluation method for the characters that make them so [7].

However, what escapes is a strong ambivalence between their constituent structure, which is inherently resilient, and the tendency to fragility $[7,8,13,14]$. Rural areas are under considerable pressures, some of these are soil consumption, intensification and monospecificity, the presence of pesticides in water and the abandonment of agriculture and related assets $[16,17]$. We know that a cultural rural landscape is resilient as long as the community persists in traditionally cultivating it. The problem arises when the community 
abandons it and interrupts its production and its care, with consequent environmental problems (hydrogeological), cultural problems (loss of tangible and intangible heritage) and socioeconomic problems (loss of attractive economies). This can happen both in cultural landscapes and in ordinary ones, because many rural systems around the world are subject to continuous depopulation $[16,17]$.

There are numerous policies, projects and strategies concerning the possible regeneration of marginal territories in depopulation. In Italy, the National Strategy of Inner Areas (SNAI) [18], a cohesion policy promoted by the Italian government, provided the opportunity to bring back to the center of political and academic debates territories that had remained on the margins for a long time, with a view that it differs from simple welfare subsidies and instead promotes initiative and local growth.

In some UNESCO sites, the situation is more ambiguous. On one hand, they are fragile marginal areas, often subject to depopulation; on the other, tourist pressure is growing. The risk is to change the productive territorial identity (the same as that for which tourists are attracted) in favor of purely consumerist commercial economies.

A new vision is needed for cultural rural landscapes which abandons the principle of conservation as freezing and takes the opportunities and stimuli for the sustainable development of a new agriculture.

The goal of this contribution is to take up the multiple challenges of rural areas, trying to investigate the role of landscape design within a multifunctional agriculture model. The OECD (Economic Co-operation and Development) defines as multifunctional that agriculture which adds multiple functions to its primary role, such as protecting the environment and biodiversity, managing resources in a sustainable way and contributing to the socio-economic survival of rural areas [19]. In this sense, a landscape project inserted in a multifunctional agriculture context can maintain traditional quality production (and, therefore, also the territorial authenticity), inserting integrative activities that support local economy, and it can generate value through a rural space that will become public. In particular, the landscape project can use local resources; according to the SNAI guidelines for inner areas, it can restore the production of abandoned land, it can recover disused buildings, it can generate jobs for local people and it can provide opportunities for inclusion between tourists and residents.

We are talking about a resilient transcalar model. It is transcalar because it is not only local action but also territorial action: it is local because it restores production and integrates alternative activities; it is territorial because it fits in the village and with the rest of the region, thanks to a project of spaces and paths. It is a resilient model because it is flexible, and it adapts to the present dynamics while maintaining the intrinsic characteristics of the territorial system. In this sense, it implies a two-way vision between innovation and conservation that can generate experimental and stimulating research opportunities, aimed at protecting and regenerating cultural marginal territories.

To analyze this issue, we opted for an application on a known case study, such as the wine-growing site of the Langhe-Roero Monferrato in Italy, with reference to the village of Vignale Monferrato. We chose this case study since it is a cultural landscape, inscribed on the World Heritage List, but it is also in a continuous depopulation process.

To carry out the idea, it was decided to work on a master's thesis of the Landscape Architecture Degree of the Polytechnic of Milan (Italy) [20], built as team research between supervisors and students. This choice was not made by chance but is derived from the idea of experimenting a research-by-design method as a meeting point between research and the need to teach the design process to young students.

The paper is divided into materials and methods (Section 2), which describes the applied approach, the analytical case studies and the application case study that led to the model's definition; results (Section 3), with the illustration of the project; discussion (Section 4), with the results' interpretation and conclusions (Section 5), with the identification of scenarios and possible guidelines for new future developments on the theme of rural landscapes, from a regenerative and resilient perspective. 


\section{Materials and Methods}

\subsection{Approach and Method Adopted}

The approach adopted in this work draws on the school of research-by-design, a type of academic investigation of the architecture field (in particular, landscape architecture and urban design), through which design is explored as a method of inquiry [21,22]. We chose this methodology for several reasons. The first concerns the aptitude of this approach to become a link between research and project. The second reason concerns the particularity of being suitable for dealing with problems and systems that require constant adaptation, such as landscape [21,22]. The difference between science and research-by-design lies precisely in distinguishing between analytical study actions and ongoing project actions [21,22]. We chose this method also because we are in a didactic process, and we know that this approach implies a project that is not only an action but a real cognitive process, made up of mechanisms of composition and decomposition and of elaborations of possible future scenarios.

The didactic process, proposed here as a process of shared knowledge building, represents a precious opportunity to undertake an experimental research path. In this case, there is the opportunity to build a structured and conscious methodology, in which each step is explained and understood with awareness of the diachronic and spatial implications.

The teaching process is based on case studies, which represent important learning and research opportunities. On one hand, the analytical case studies are useful to deconstruct the logic that generated them and to extrapolate positive and negative aspects, elements of replicability and lines of development. Avoiding the effect of compiling data collection, it is a useful exercise for students to understand how the research and study phase must precede the project, developing and building a critical and constructive point of view. On the other hand, the application case study represents an opportunity to apply the hypothesized strategy, with related considerations in terms of possible what if scenarios. As part of this phase, the methods and tools adopted are many, but all are based on a strong anchoring to the historical and traditional place roots, in line with a European territorial approach. In the current case of a cultural rural landscape, we talk about historical traces that coincide with ecological ones. For example, we talk about edges and green infrastructures that have accompanied the productive landscape over the centuries and that have disappeared with mechanization. The study of land use through historical maps and past satellite images will guide the restoration of a traditional agricultural landscape and of a better ecological condition in terms of both biodiversity and hydrogeological safety.

The territorial planning action also becomes an important educational opportunity to understand the ambivalence of the relationships between cause and effect; local scale and macro-scale; socio-economic and political dynamics; spatial and geographical dynamics; natural sciences, social sciences and design sciences and much more.

\subsection{Analytical Case Studies}

EU Member States have tried to respond to the challenges and opportunities facing rural areas in the 21st century by developing the EU's rural development policy: the Common Agricultural Policy (CAP) [23]. The CAP supports rural areas to face up to the wide range of economic, environmental and social challenges that such fragile systems will face. It has been proposed to achieve the following strategic objectives: to foster the agriculture's competitiveness, to guarantee the sustainable management of natural resources, to structure actions to combat climate change and to achieve balanced territorial development of rural communities. The EU rural development policy is implemented through Rural Development Programs (RDPs) and through several projects focusing on resolving demographic decline and developing rural communities [23].

In the teaching process, 12 European case studies of agriculture were analyzed, mostly financed through the European Agricultural Fund for Rural Development (EAFRD), but also with national or regional and private contributions. Following the analysis of these case studies, it is possible to identify the two main aspects that feed rural regeneration projects. 
The first concerns the agriculture's multifunctionality, capable of providing alternative incomes and generating conditions for choosing quality production. Within this aspect also fall educational activities regarding traditional local skills, which are a cultural resource that can become the subject of courses and supplementary activities for the farm. The second aspect concerns a chance to recover the great abandoned rural heritage, which includes land but also buildings. These are underutilized local resources that can fuel regeneration projects.

To undertake a specific study on open space design, an analysis of these 12 farms in relation to their model and spatial structure was conducted. Most of the spaces in the cases analyzed are obviously dedicated to agricultural production, and the paths are distribution axes that connect the entire property, also becoming a public space open to visitors who explore the estate.

Following the study of analytical cases, we moved on to the application case.

\subsection{Application Case Study}

\subsubsection{Regional Analysis}

The territory considered as an applicative case study is that of Vignale Monferrato, a village that is part of the Italian Langhe-Roero Monferrato wine landscape in the Piedmont Region in north-western Italy, halfway between the two large metropolises of Milan and Turin (Figure 1).
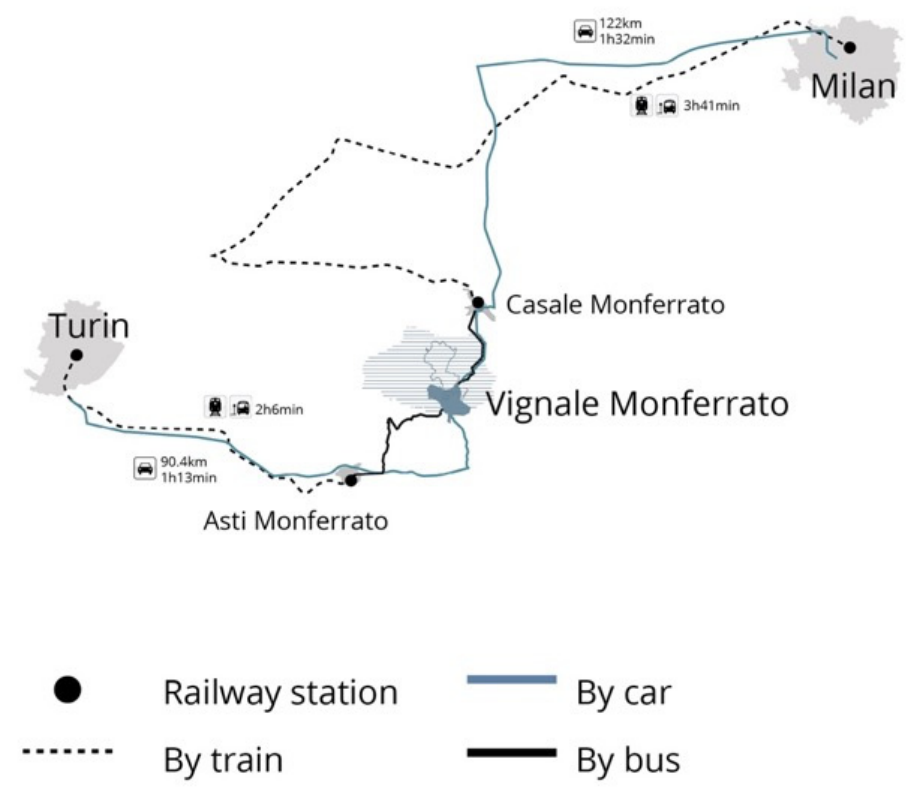

Figure 1. Location and access to Vignale Monferrato (source: Elaboration by Zhang, Zhang).

The municipality of Vignale is located in the province of Alessandria, on the border with the Province of Asti.

In the Regional Landscape Plan [24], Vignale Monferrato belongs to the "Monferrato and Casalese plain" area (Figure 2). This area is delimited by the hills of central Monferrato (north-west); the Po river area, the main river of the north Italy (north-east), ands the alluvial terraces of the Tanaro river (south).

The settlement system is mainly of high ground; in particular, the south hilly relief (where there is Vignale Monferrato itself, $300 \mathrm{~m}$ above sea level) develops with weak slopes and slightly accentuated differences in height; on the other hand, the northernmost area (Verrua Savoia, Moncestino, Gabiano) has greater slopes. This morphological distinction is also manifested in the land use, which is predominantly agrarian in the first case (maize, wheat, vineyards and wood arboriculture), while it becomes predominantly forest in the second. Regarding the composition of the woods, in addition to the Black Locust, there are chestnut groves in recession with reserves of oaks (Downy Oak and sometimes Turkey 
Oak). To the north, there is the Po plain, strongly characterized by the use of rice and with, near the watercourse, poplar cultivation, spontaneous formations of willows (shrubs and trees) and poplars next to robini, with some cases in deterioration due to the presence of invasive alien species (Sicyos Angulatus, Reynoutria Japonica). There is also a strong presence of white mulberries in natural decline and abandonment.

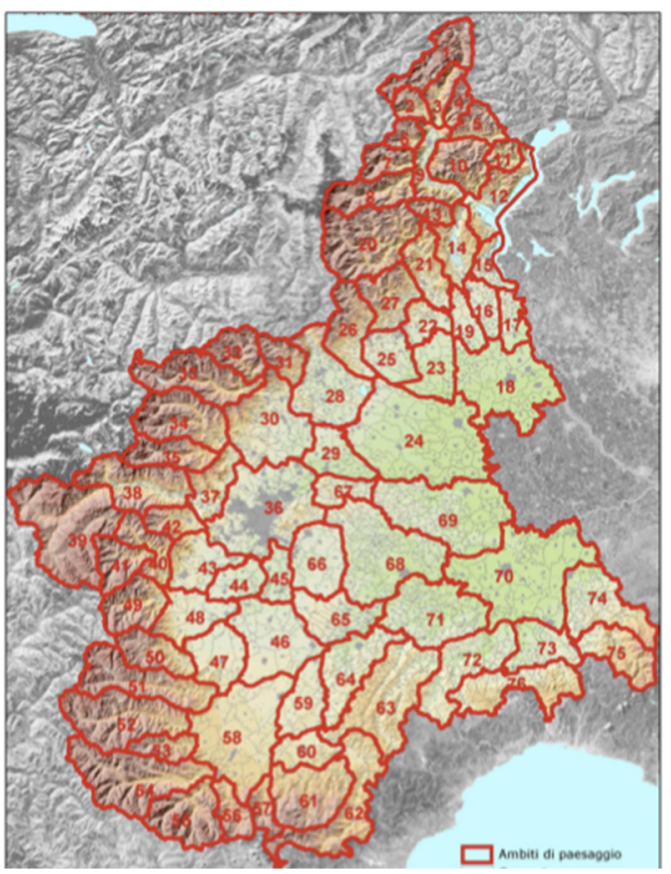

(a)

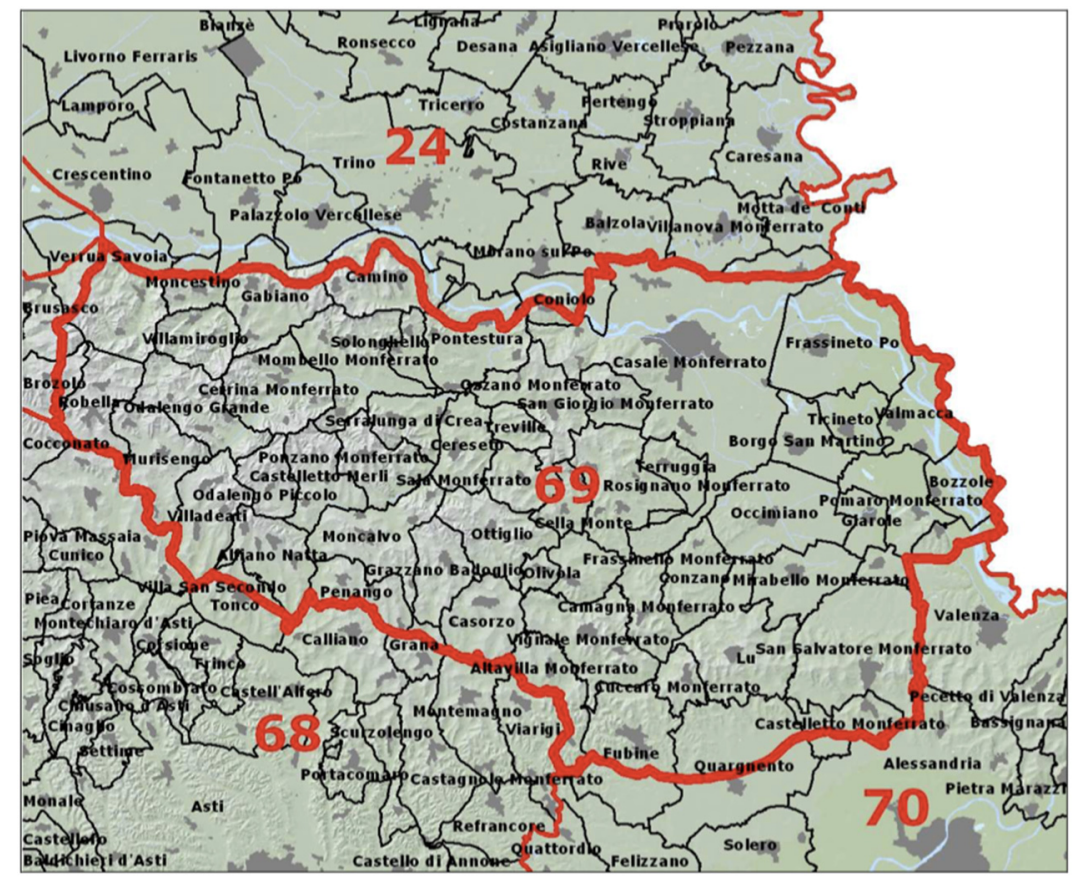

(b)

Figure 2. Landscape area of the site ( $\left.n^{\circ} 69\right)$, recognized by the Regional Landscape Plan, at the scale of the Piedmont region (a) and in detail (b) (source: Regional Landscape Plan of Piedmont).

In this area, there is a protected areas system of the river belt, and in particular, the two large Natural Reserves (also SIC and ZPS) of Ghiaia Grande and of the Confluence of Sesia and Grana are very important from a naturalistic point of view.

The Monferrato territory is also part of a World Heritage site, recognized in 2014, with the caption "Vineyard Landscape of Piedmont: Langhe-Roero and Monferrato" [25,26]. The OUV (Outstanding Universal Value), which motivates the inclusion in the World Heritage List, is determined by the landscape harmony associated with the production of wine and ancient winemaking. The criteria used to prove inclusion in the UNESCO List are: criterion III, which describes the exceptional living testimony of the winemaking tradition; criterion $\mathrm{V}$, which sees in the vineyard as an excellent testimony of man's interaction with its natural environment $[25,26]$ (For the meaning of OUV and the list of UNESCO criteria, see whc.unesco.org).

The UNESCO property is divided into six components that fall within the boundaries of three provinces: Alessandria (AL), Asti (AT) and Cuneo (CN). In this paper, we deal with a project area located in the municipality of Vignale Monferrato, which is part of component number six, "Monferrato of the Infernot" (Figure 3).

From the historical-settlement point of view, there are two Roman roads: the first runs parallel to the course of the Po river, in an east-west direction; the second is transversal and led from Asti to Vercelli. It should be emphasized that the area corresponds to the core of the Marquisate of Monferrato, which survived independently until the Treaty of Utrecht (1713), and it presents cultural peculiarities that have left evident traces in art and architecture [24,26]. The general settlement characteristics are profoundly different between the hilly area and the one close to the Po river $[24,26]$. In the hilly case, the settlement is centralized, high ground or a ridge; only during the 19-20th centuries, with the gradual 
spread of the railway network, the first commercial settlements appeared in the valley bottoms, gathering points for agricultural and wine production. The historical settlement structure dates to the final centuries of the Middle Ages and seems to have been oriented by the foundation of some settlements (Brusasco, Villamiroglio, Montemagno and Pontestura) and castles (Montiglio, Gabiano, Moncalvo and Conzano). In the area of the Casalese plain, the settlement has the form of newly founded villages (13-15th centuries: Frassineto Po, Borgo San Martino, Occimiano and Mirabello) or scattered nuclei, sometimes developed starting from an agricultural castle (15-16th centuries: Valmacca, Giarole, Baldesco and Castel Grana).

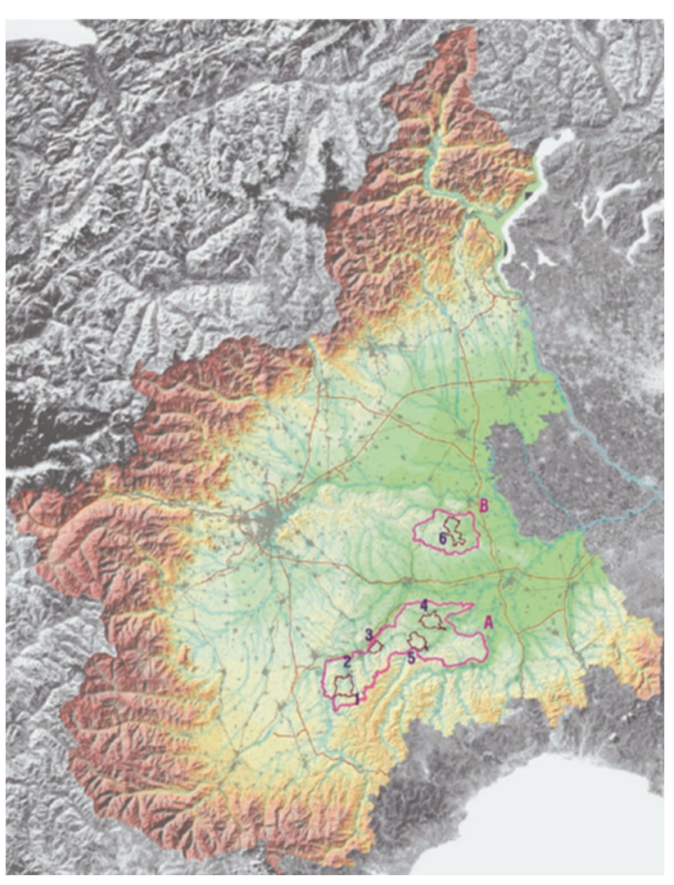

(a)

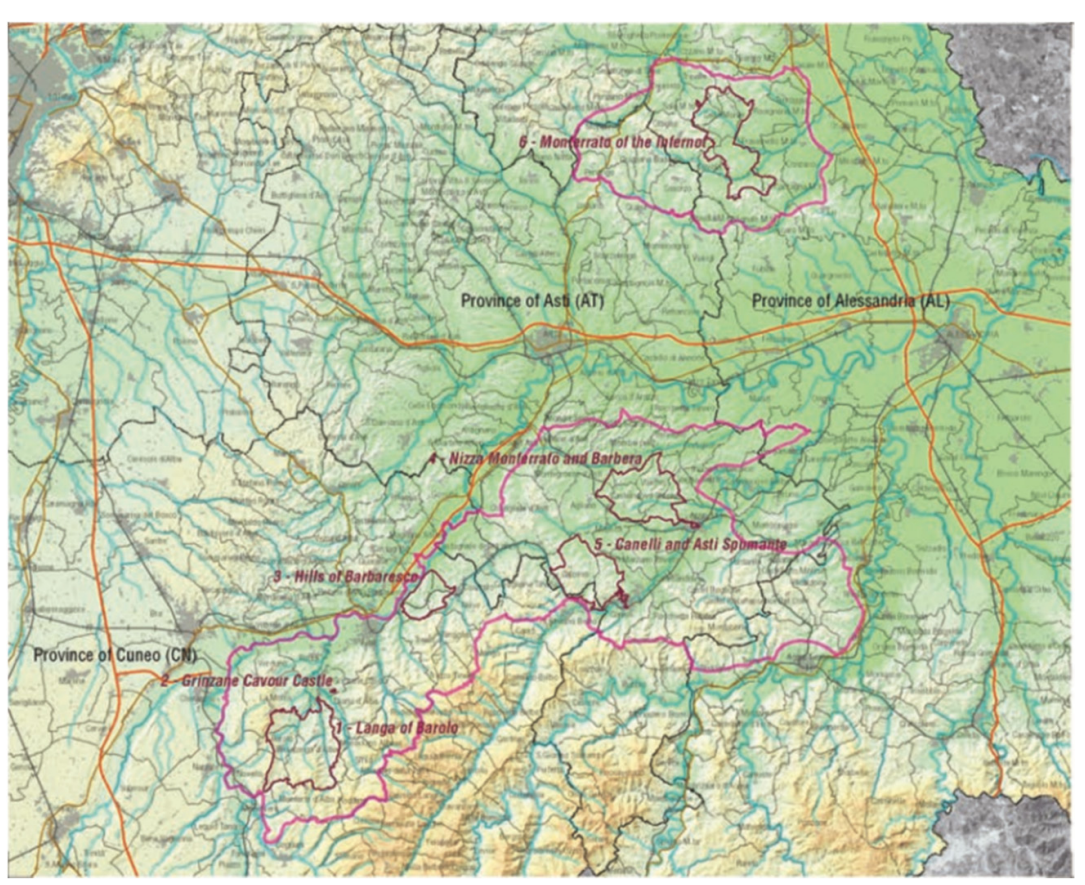

(b)

Figure 3. The boundaries of the UNESCO site "Vineyard Landscape of Piedmont: Langhe-Roero and Monferrato", on a regional scale (a) and on a more detailed scale (b). The site covered by this paper is located in Vignale Monferrato, a municipality located within area no. six, "Monferrato of the Infernot" (source: UNESCO Nomination Book).

There is also the presence of extractive activities, consisting in the cultivation of clay, gypsum and concrete aggregates quarries. In particular, the area between Ozzano, Coniolo and Casale, thanks to the composition of the marl deposits, has historically been involved in mining-manufacturing activities related to the production of cements [24].

The most critical aspects of this described territory, identified by the Regional Landscape Plan, mainly concern, on one hand, the abandonment of traditional villages and economic activities and, on the other, the excessive tourist characterization [24]. In particular, we are talking about (a) the uncontrolled and disqualified residential expansion of second homes, both in hills and in plains; (b) the tendency towards clogging of the valley floor with productive activities; (c) the abandonment phenomenon, with the related negative consequences for the territorial balance (the historical building heritage, which, after abandonment, suffers the speculative phenomena effects); (d) agricultural transformations (on one hand, the abandonment, with the erosion risk due to lack of maintenance, the re-naturalization and the replacement of vineyards with high visibility ground-based photovoltaic systems; on the other hand, the risk of a excessive crop specialization, with reduction of biodiversity and loss of soil quality) and (e) the specific risks of the Po plain, such as frequent flooding, the spread of exotic shrub species, reduced riparian forest vegetation and the desiccation of river beds. 
The Regional Landscape Plan outlines some guidelines to stop these fragilities [24]: the containment of urbanization dynamics and the protection of areas that have maintained recognizable cultural assets, the recovery of abandoned buildings, the containment of transformations for rural nuclei and for the spread of single-family-type settlements, the containment of productive settlements and the protection and enhancement of archaeological assets, such as castles.

For the naturalistic and rural aspects, the guidelines are [24] encouraging an increase in wood arboriculture areas and the reconstitution of new vineyards plants; in order to limit excessive water consumption, irrigation must be rationalized; in order to improve the quality of hilly wooded formations, management must maintain or recreate the populations with the most natural composition possible; the aged coppice woods, aged over 35-40 years, must be raised to high forest, and the sporadic native species and large trees must be preserved; erosive phenomena must be contrasted with the constant maintenance of an efficient drainage network.

\subsubsection{Local Analysis}

The project site is located in Vignale Monferrato, in the province of Alessandria and in the previously described territory of Monferrato. Currently, 946 inhabitants live in Vignale, of which $49.7 \%$ of the total population is over 55 years old [27]. The old age index is currently $393.5 \%$ [27].

Despite this dramatic and ever-worsening picture, Vignale and its context are very rich from an environmental and cultural point of view, with deep connections with winegrowing activity (as can be understood by the etymology of its name, Vinealis, which means winebearing soil). The proximity to the river Po, the altitude and the hilly morphology have made this area suitable for the cultivation of vineyards and for the production of a highquality wine. It is a promising heritage which, thanks also to the UNESCO recognition, represents an important opportunity [26]. The rest of the territory has wooded areas (around the settlements), meadows and agricultural fields with arable land (Figures 4 and 5).

The Vignale landscape is composed by a centralized settlement arranged on the hill, with iconic buildings that represent the village central point. A fundamental building for Vignale is Palazzo Callori, home to the Regional Enoteca del Monferrato, whose construction dates to the 15th century. The Church of San Bartolomeo is located in the north of Piazza del Popolo, and it is an imposing building built in the 18-19th century. The square to the west allows a view of the Monferrato hills. These building complexes of high historical and architectural value, together with the squares and streets, constitute the heart of the town, and they represent the collective sense of belonging to the strong cultural identity [28]. The other residential buildings are distributed around the basic structure of the main historical settlements.

From an accommodation point of view, in addition to hotels and restaurants, agritourism is one of the most frequent hospitality forms and is the main form of support for tourism demand but also for the farm itself [29]. Usually surrounded by vineyards and orchards, agritourism allows visitors to get in touch with the landscape.

The wineries are mostly located around the vineyards and are an important part of the wine production chain, as they are open to the public with visits and tastings. The entire wine production, with relative storage and distribution, takes place entirely on site.

The territory assumes a fundamental social and economic role of great tourist attraction, linked not only to the production of wine, but also to other typical products, such as white truffles, a local variety of apples, red celery dating back to the seventeenth century and others.

Tourism, here élite and not mass tourism, is the economic response to an exceptional cultural landscape that is characterized by all the elements that revolve around agricultural production: not only the wine product itself, but also the historical artifacts and artistic activities related to agriculture, environmental quality, landscape itineraries, traditional crafts, food and wine-themed events and festivals and much more (Figure 6). 


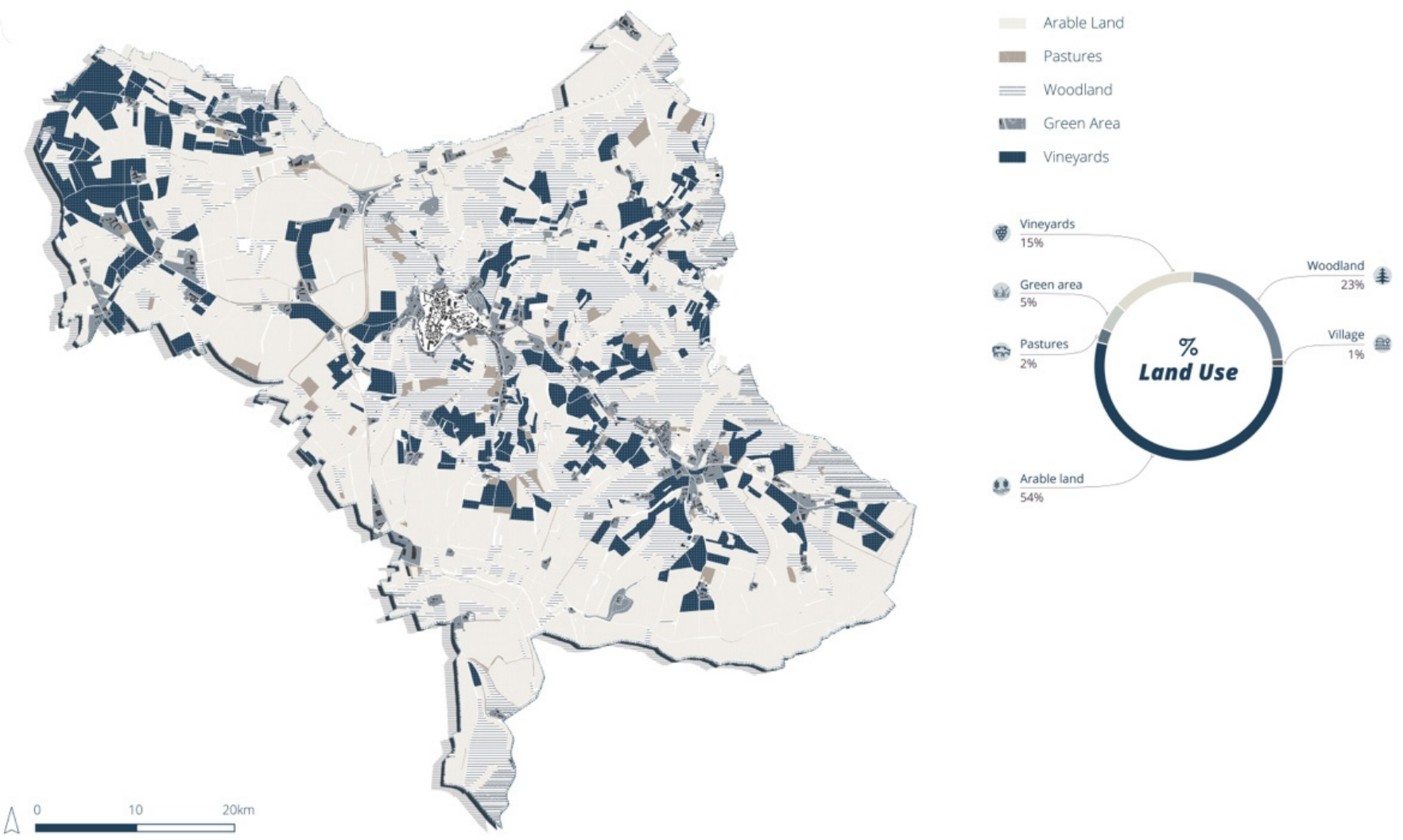

Figure 4. Land use in Vignale Monferrato (source: Elaboration by Zhang, Zhang).
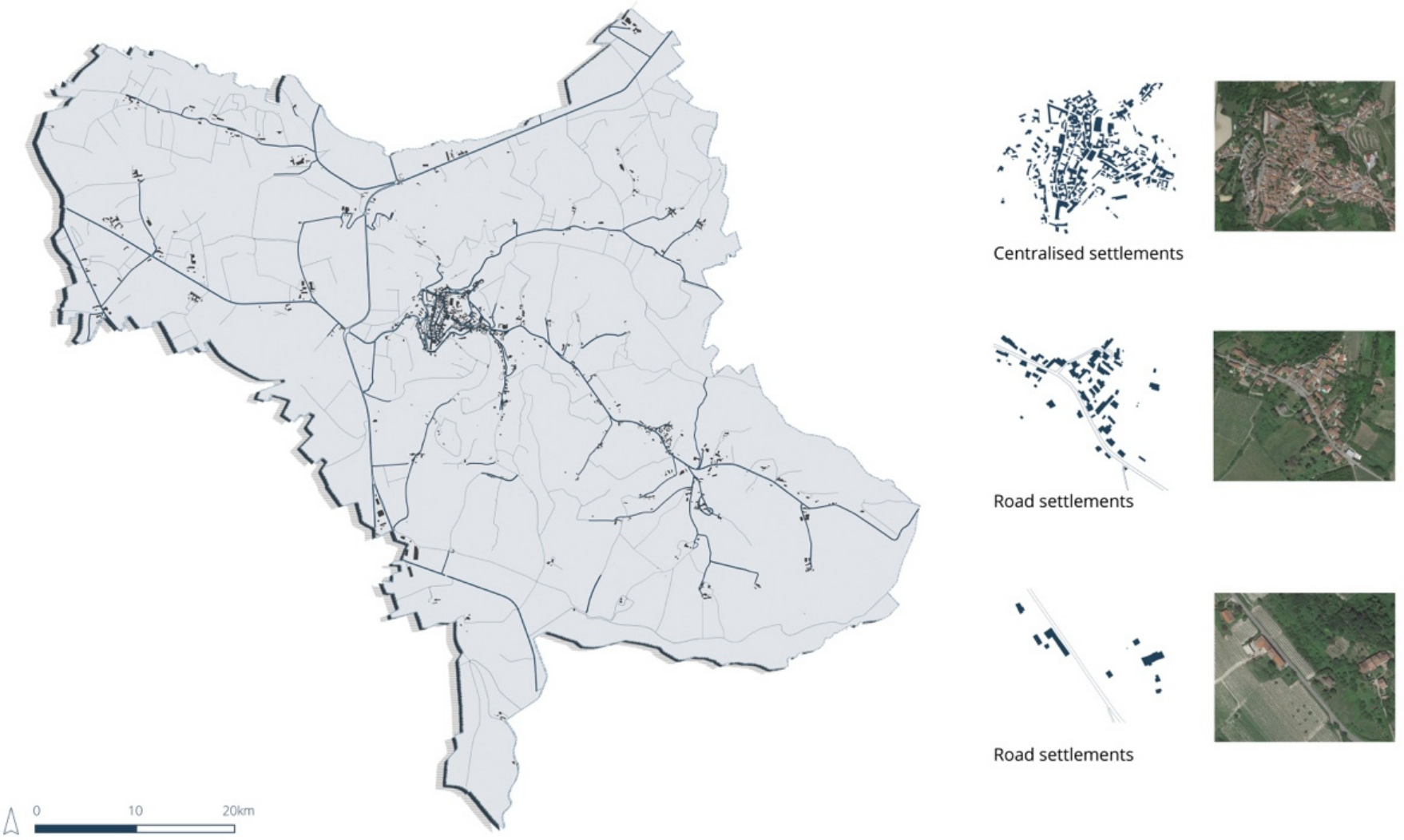

Figure 5. Settlement layout in Vignale Monferrato (source: Elaboration by Zhang, Zhang). 


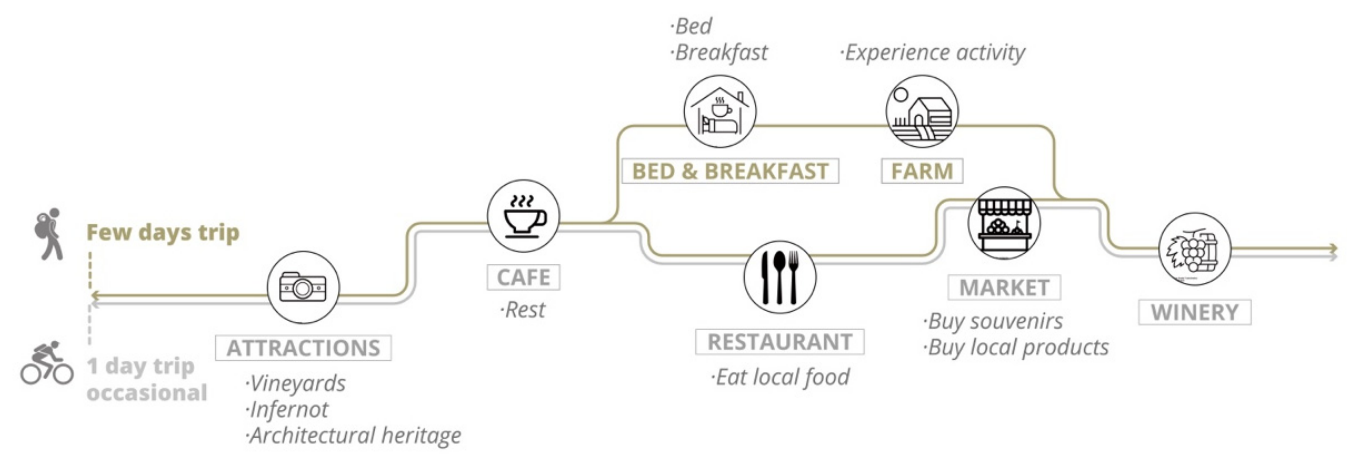

Figure 6. Existing tourism model in Vignale Monferrato (source: Elaboration by Zhang, Zhang).

There are also two slow paths that cross the town but which are part of a larger system: (1) the greenway planned for the Piedmont area and (2) a slow route that starts from Alessandria and crosses nine villages in the core area of the UNESCO site.

Always in the surrounding area, there is the VENTO project: a $780 \mathrm{~km}$ cycle path funded by the Italian Ministry and designed by a research group of Milan Polytechnic, which aims at the economic regeneration of the small villages located on the Po river line $[30,31]$. VENTO, while not crossing our site directly, can generate a quality tourist context, favorable to the inclusion of the proposed project.

\subsection{The Model}

What is proposed here is a multifunctional agriculture model, which integrates production income with university fees from educational courses (Figure 7). We are talking about the Farmer Incubation Program [32]. The Farmer Incubation Program is an applied education program that aims to support the growth of new farmers. It provides new farmers temporarily with land, infrastructure and training to develop skills and start an agricultural business. These programs train young farmers to overcome the obstacles faced by beginners starting a business: access to land and capital and the opportunities to learn and develop skills in planning agricultural activities.

To implement the model, four of these programs were selected to study their mechanisms and the amount of training fees (Pop-up Garlic Farmer in Melbourne; Future Growers Program in Bristol; Farm Start in Stockport; Commercial Growers Short Courses in Stockport). The courses can have very variable durations, which allow a flexible turnover of the farm. The main contents refer to the enhancement of local resources, in all their forms, and to the guidelines of the 17 UN Goals.

To undertake this model, it is possible to recover abandoned lands with the main goal of training and education. In this way, a multifunctional area has been imagined that includes production, a school of viticulture, a small museum and an agricultural park. In this sense, job places can be generated that are partly temporary (for example, internships for those who finish courses) and partly permanent. The whole project is a process of interaction and integration between the various stakeholders, between visitors and residents and between farmers and young students. 


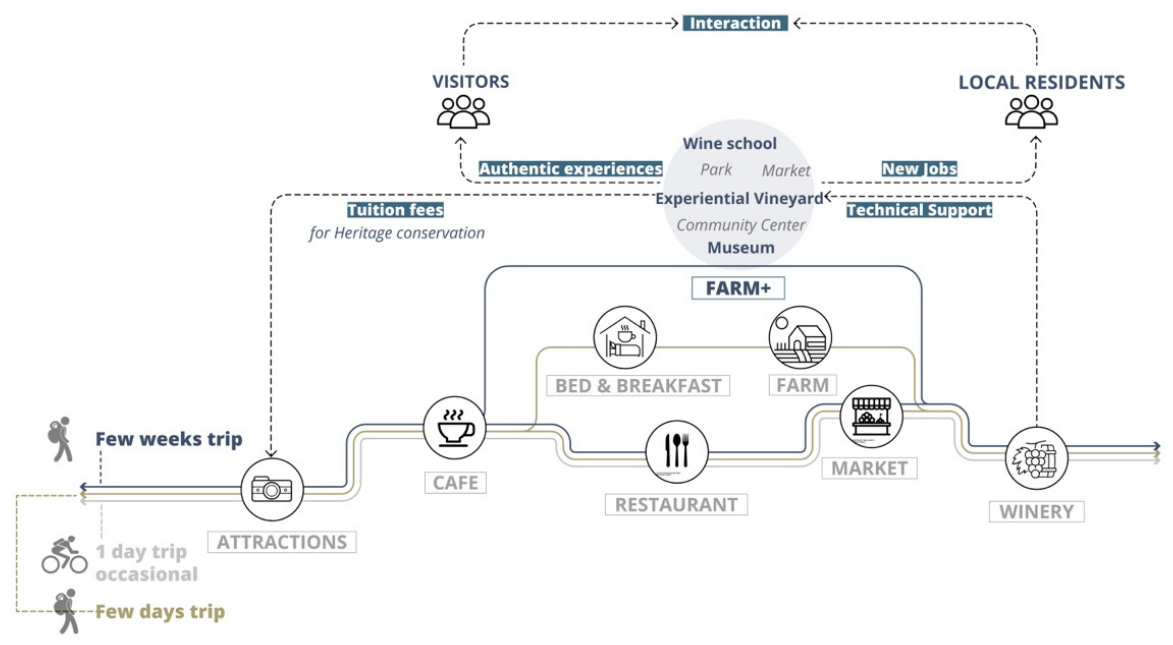

Figure 7. The proposed model for Vignale Monferrato (source: Elaboration by Zhang, Zhang).

\section{Results}

Hypothesizing a scenario for the proposed model, regarding activities and flows of people, is fundamental for structuring the landscape project. The spatial needs of a multifunctional educational farm, in a tourism context, can be summarized in three types: spaces for rest, both for guests but also open to the public outside; spaces for recreation, events, cultural festivals and cultural exhibitions and spaces for didactics, for all types of students (brief and long time).

Two other fundamental aspects that can guide the choice of the site are (i) the need for agricultural land to be recovered for not only productive but also training purposes and (ii) the need for a building to allocate functions that require internal spaces.

Starting from these needs, a site was identified adjacent to the center of Vignale, in the Buffer Zone of the UNESCO property (Figure 8). The location is interesting for generating interaction with the residents and with the local economic activities. Furthermore, at this point, it is possible to take the opportunity to intercept the itinerant route that starts from the center of Alessandria. In this way, the project would be placed in a wider regional system, and it would be possible to meet the regeneration opportunities that slow lines have always been able to offer [29-31]. The identified site is an open space of about 3.7 ha, publicly owned, to the north-east of the town.

\subsection{Description of the Project Site}

The site extends longitudinally in the eastern end of the historic center, and it has the potential to integrate with the Vignale existing open space network. The road structure of the town is a ring, and the site is adjacent to the SP68 road. Along this road, there is a large public car park, the largest in town. There are only two bus stops in the eight villages of the Core Zone 6, one of which is located less than $100 \mathrm{~m}$ west of our site. Therefore, the site is easily accessible not only by car or bike, but also by public transport (Figure 9).

From an ecological point of view, we can say that the site was of rural origin, but now it is unused. None of the plants present are listed in the territorial plans nor in the UNESCO Nomination Book. There is uncultivated green that is mainly weeds and shrubs, with a few trees on the road borders (some Prunus Pissardi Nigra trees and several shrubs of the willow family, such as Salix Purpurea), and the rest is mostly cemented.

There are four abandoned buildings on the site (Figure 11): an abandoned factory, two warehouses and a former social cellar (Figures 12 and 13). The social cellar (Cantina Sociale) is the oldest building, dating back to the mid 1950s, which was once the territorial production activities hub, closed in December 2011, and has been in a state of neglect for many years. It is a rural building with large concrete silos, which recalls the winemaking tradition of these territories. The structure is in reinforced concrete, and the roof is made of 
asbestos cement plates. The other three buildings are from a later period, and none of them are listed as protected in the planning instruments or in the UNESCO Nomination Book.

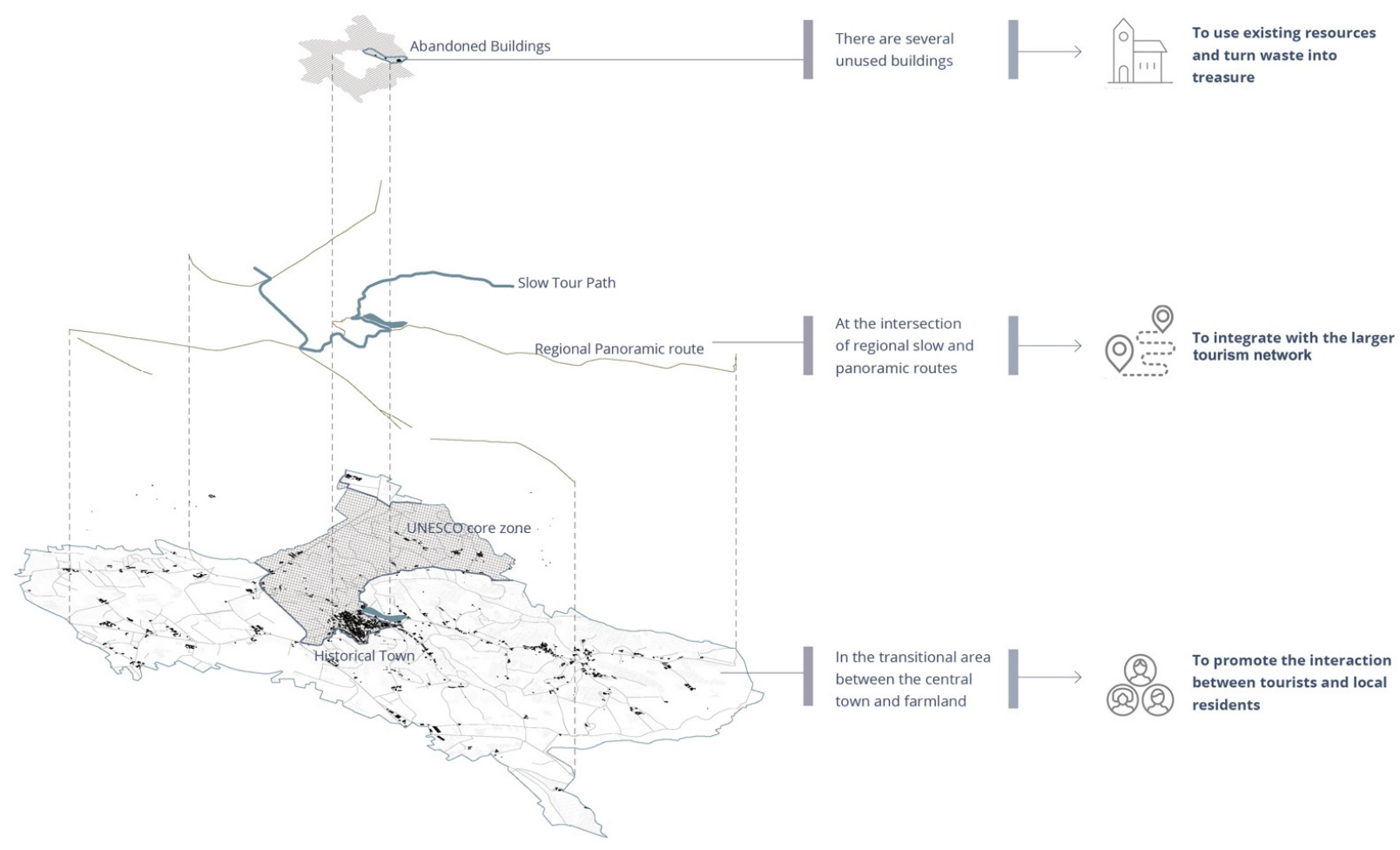

Figure 8. The site selection (source: Elaboration by Zhang, Zhang).

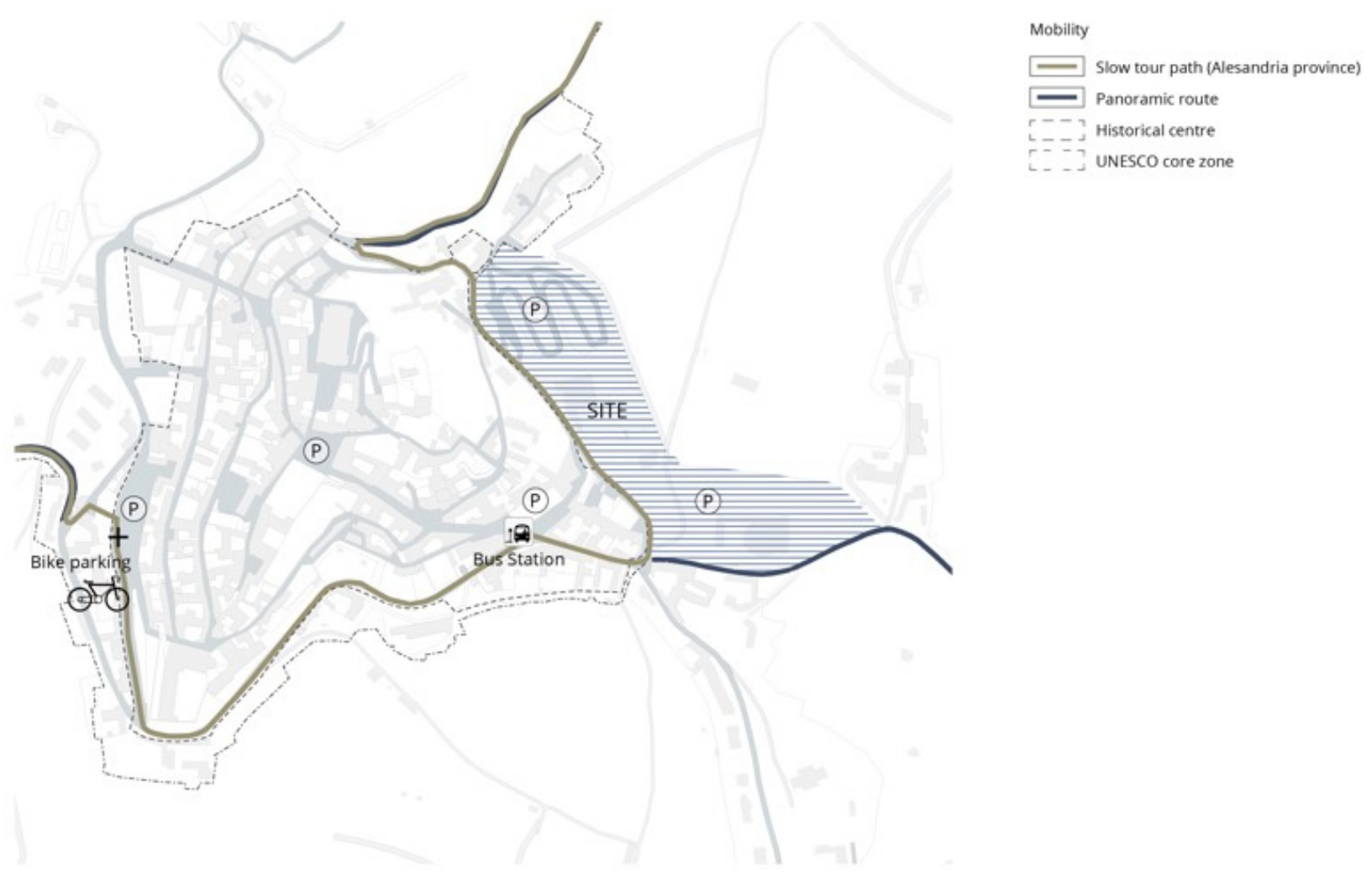

Figure 9. The relationship between site and the UNESCO core zone (the historic town) (source: Elaboration by Zhang, Zhang). 
Through the study of past satellite images, it was possible to reconstruct the recent evolutionary process (Figure 10). In the 2001 map, the northern part of the site was not a parking lot but agricultural land (Figure 10a). Construction of the car park began in 2011. In addition, the vineyard on the east side of the site has turned into hazelnuts. Comparing the situation of 2021 with that one of 2013, we found that the pavement of the eastern car park was damaged by spontaneous vegetation.

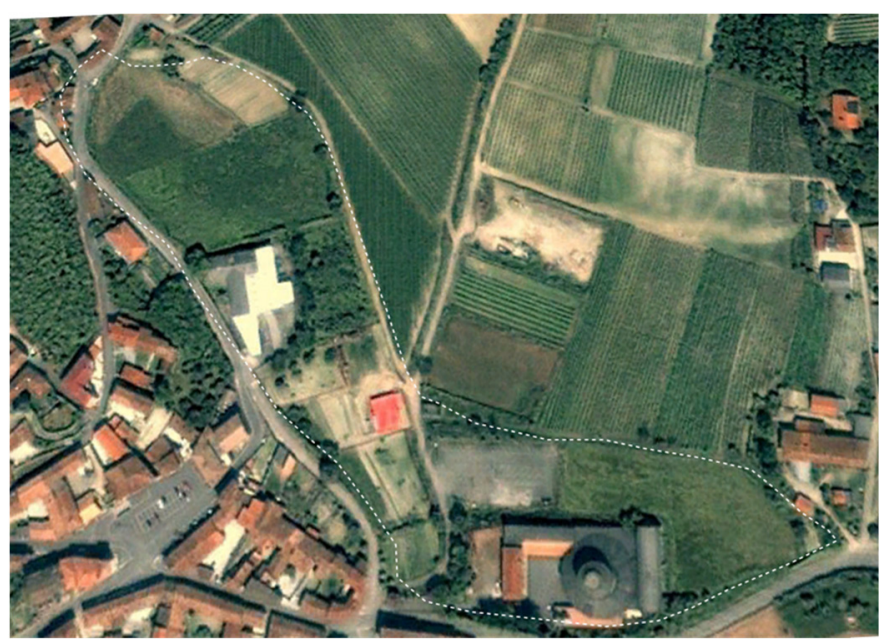

(a)

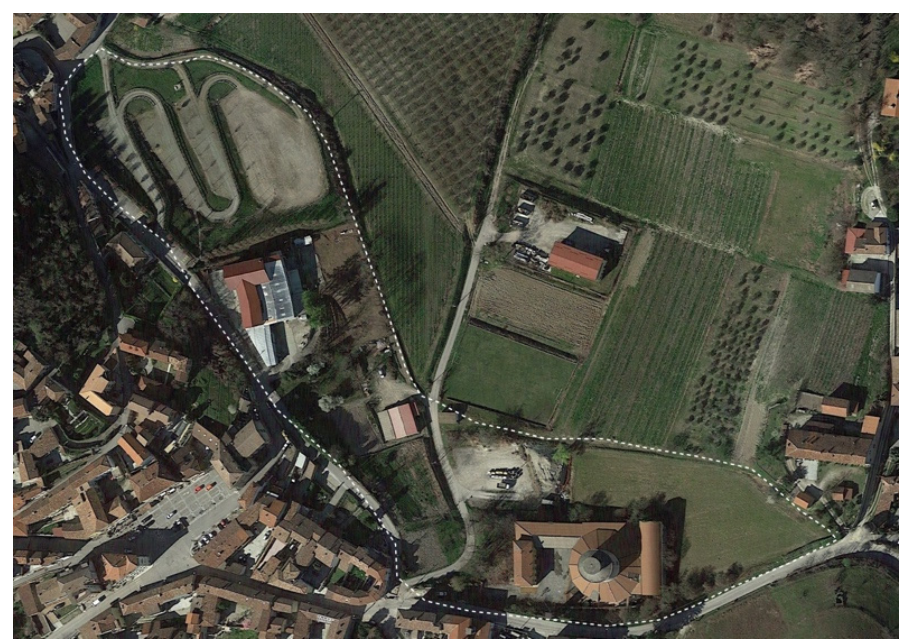

(b)

Figure 10. Two aerial photos of the site: one of 2001 (a) and one of 2021 (b) (source: Elaboration by Zhang, Zhang).

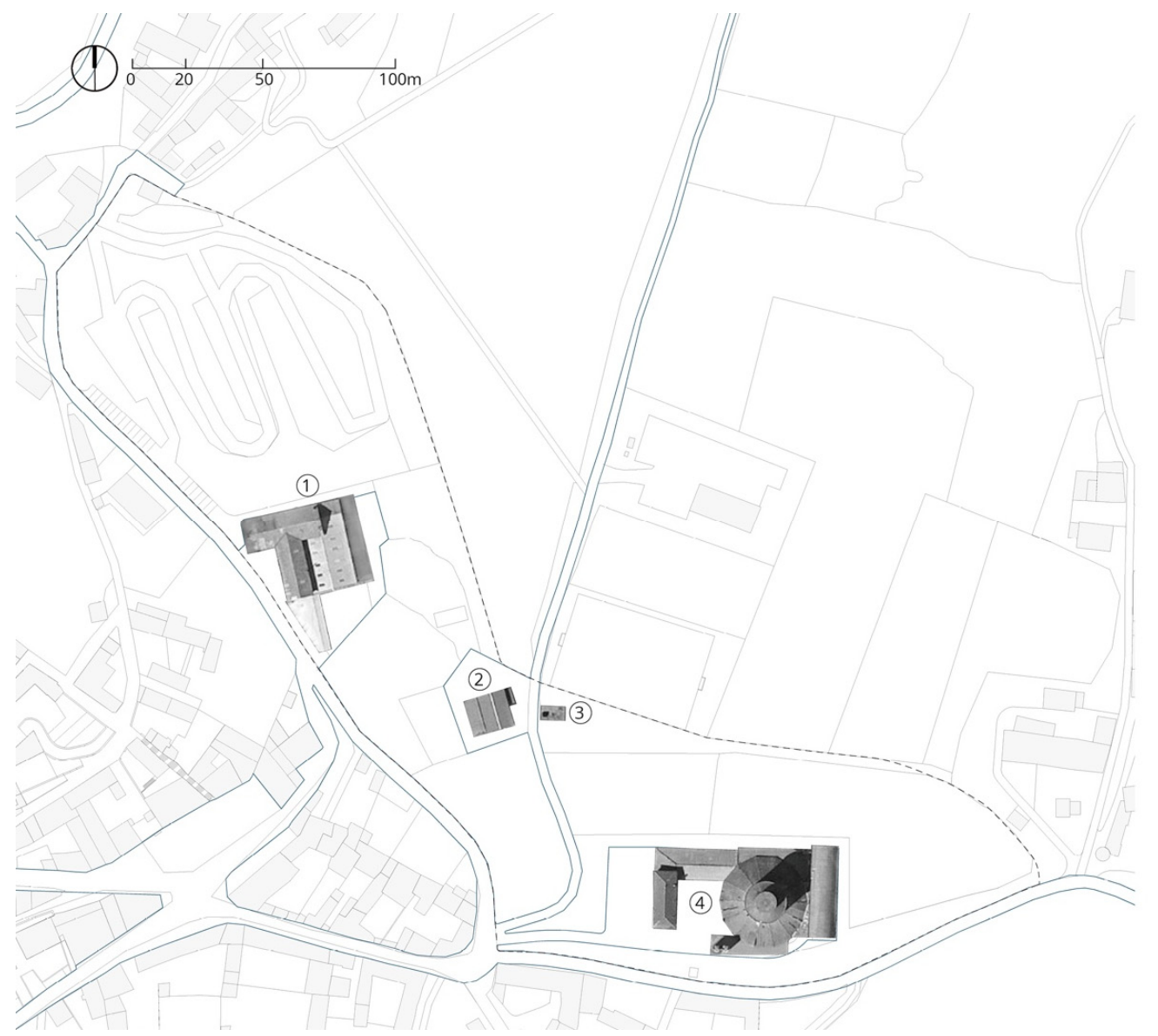

Map of the abandoned buildings within the site

(1) Current: Factory

(2) Current: Warehouse

(3) Current: Warehouse

(4) Current: Former social cellar

Figure 11. Map of the abandoned buildings within the site (source: Elaboration by Zhang, Zhang). 


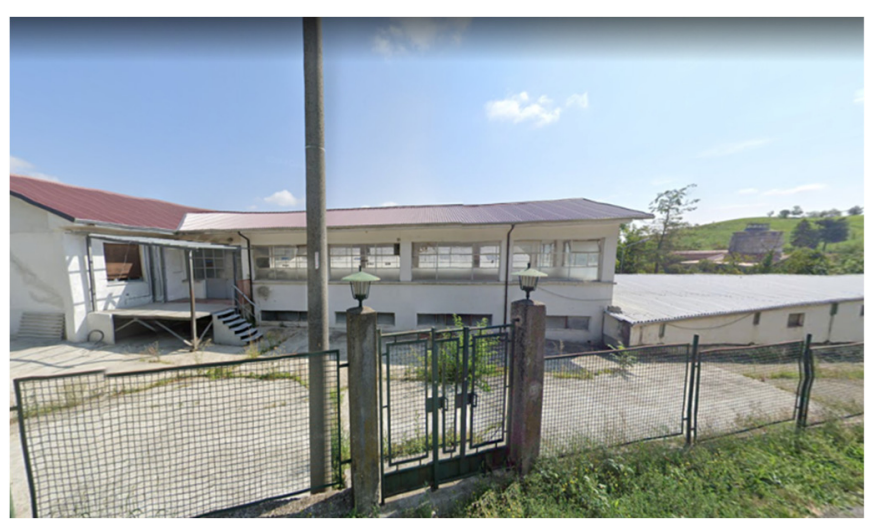

(a)

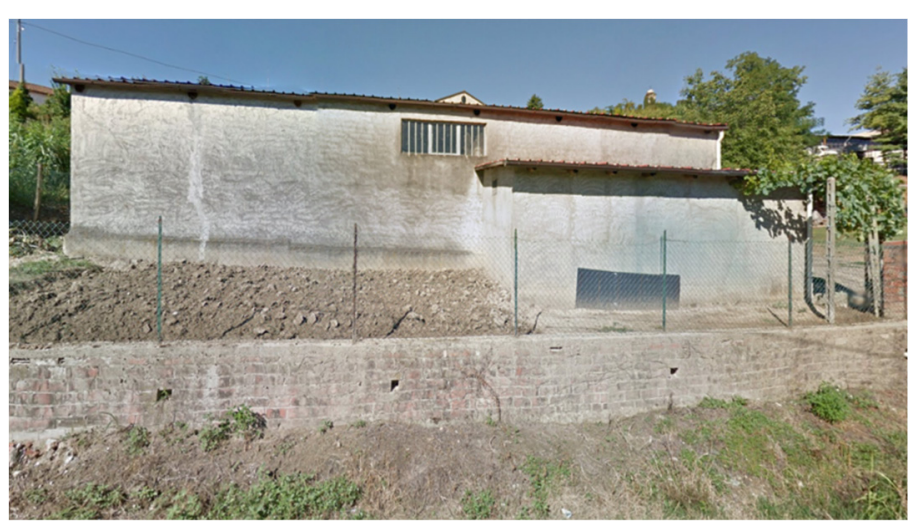

(b)

Figure 12. Buildings no. 1 (a) and no. 2 (b) (source: Elaboration by Zhang, Zhang).

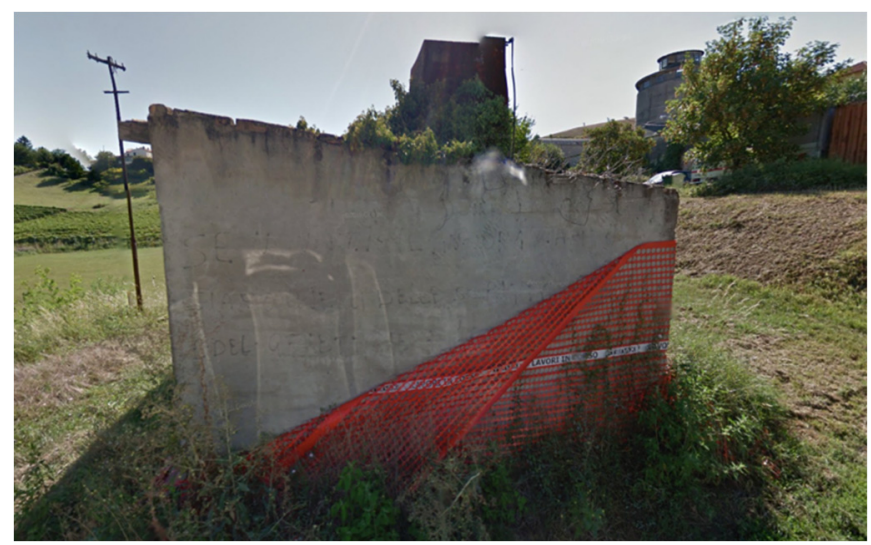

(a)

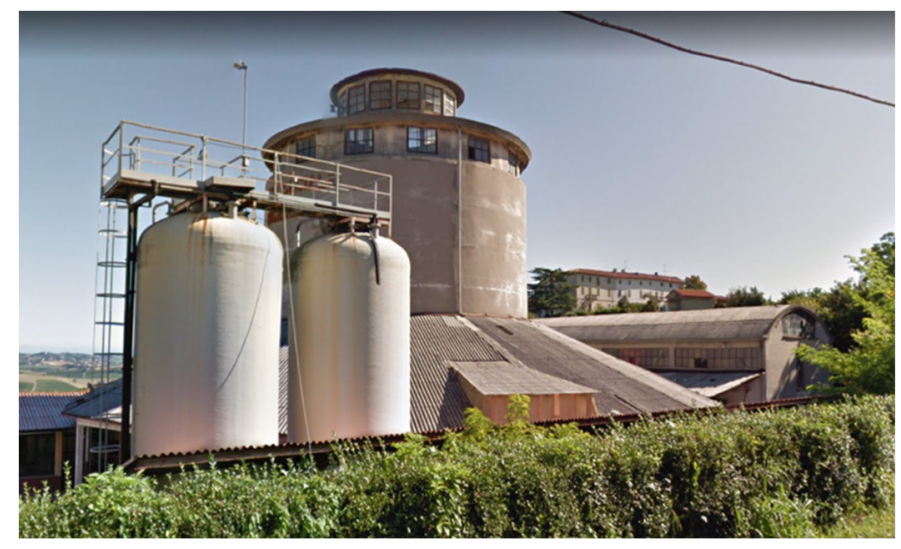

(b)

Figure 13. Buildings no. 3 (a) and no. 4 (b) (source: Elaboration by Zhang, Zhang).

\subsection{The Design Process}

With a view of proposing an integrated landscape project, we imagined a multifunctional wine-growing area, with a school for young winemakers, a wine museum, catering services and highly biodiverse wine-growing areas, open to tourist and recreational use, with rest areas and bike parking.

Through the needs analysis of the management model, different types of functions were identified to be placed inside the buildings. Depending on the size of abandoned buildings and on the type of original space, the different functions were suitably integrated.

The recovery of the buildings refers to four instruments, which, when suitably integrated, will provide the guidelines for the interventions to be made: (a) Law 378 of 24/12/2003 on the Protection and Enhancement of Rural Architecture [33]; (b) the Landscape Report of the dpcm 12/12/2005, as an evaluation tool for interventions [34]; (c) the Criteria and Guidelines for the Landscape Protection, developed by the Piedmont Region, which represent general principles that are not prescriptive but provide a direction for quality interventions aimed at regional territory [35] and (d) the Guidelines for the Adaptation of Regulatory Plans and Building Regulations to the protection indications for the UNESCO sites of the Piedmont Region (drawn up for the UNESCO site in question of Langhe-Roero and Monferrato) [36]. Referring to the latter, the following objectives have been pursued, relating specifically to the Buffer Zone of the UNESCO property: (1) the maintenance of the wine-growing use for the Buffer territory; (2) protection of wine places through recovery and enhancement interventions (vineyard and traditional forms of cultivation, artifacts related to cultivation and production of wine and winemaking and places and public 
spaces for wine marketing); (3) conservation and enhancement of the rural-urban historical building heritage and settlement structures; (4) protection of aesthetic value contexts, with particular attention to the visual relationships between Buffer Zones and Core Zones; (5) maintenance of the articulated and plural image of the Piedmontese wine landscape; (6) containment of land consumption and (7) mitigation of any pre-existing building impacts and enhancement of the access roads to the UNESCO site.

For the social cellar (building no. 4, Figure 13b), a conservative restoration intervention was planned to occupy a wine museum, and it can also host educational activities related to winemaking. With regards to the other three buildings, in accordance with the previously defined instruments, restructuring, maintenance and adaptation of the structures were planned, in compliance with the existing volumes and morphological and typological characters (although they are not protected or historical buildings). The two warehouses can be used as didactic spaces and services related to viticulture. In particular, one will become a "Workshop site", with a school for young winemakers (building no. 2, Figure 12b), and the other one will be a bar (building no. 3, Figure 13a). The factory lends itself to being transformed into reception services (building no. 1, Figure 12a): accommodation, restaurant, meeting rooms, rooms for events, etc.

With reference to the landscape project, we imagined the redevelopment and recovery of degraded and abandoned areas, with the inclusion of viticultural areas compliant with the existing ones (goals 1 and 2 of the guidelines [36]), and the recovery of the conditions of naturalness and biodiversity. Furthermore, following the guidelines slavishly [36], suggested interventions will be made for sites on the border between Buffer and Core Zones, such as enhancement of the access axis to the site, rest areas, lookout points, parking lots for tourism and cycle-tourism and didactic paths.

In particular, knowing that the hilly slopes are a suitable place for the cultivation of quality wine grapes, especially with slopes of $10-20 \%$, the vineyards will be placed in the sloping area.

There are no connecting roads between the various functional areas of the site, and it is possible to access them only separately from external roads; for this reason, it is necessary to introduce a functional path within the site. Furthermore, due to the hilly terrain, different areas of activity are at different height levels. Therefore, a connection design for the different height levels is necessary to facilitate accessibility for all.

To answer to these needs, it was decided to create a structured route, with a new system of open spaces along it, which then becomes a functional axis that crosses the entire site, facilitating circulation and outlining the various functional areas. The new open spaces within the site become spaces of conviviality, mainly serving the historic center/Core Zone (where some squares in the past have been transformed into parking lots, and there are no open spaces for aggregation).

Following an agroecological approach, a range of options and alternatives are available for adding biodiversity to the agricultural landscape [37]. These alternatives can involve (1) adding new species to existing cropping systems, (2) reorganizing or restructuring the species already present, (3) adding diversity-enhancing practices or inputs and (4) eliminating diversity-reducing or diversity-restricting inputs or practices. In particular, the actions that we have applied here are mainly four: (a) Intercropping: to grow two or more crops together that allow interaction between the individuals of the different crops; (b) Strip cropping: to plant different crops in adjacent strips, creating what may be called a polyculture of monocultures; (c) Covercropping: a non-crop species planted in a field to provide soil cover, usually in-between cropping cycles (it enhances soil organic matter, stimulates soil biological activity and diversity of the soil biota, traps nutrients in the soil left over from previous crops, reduces soil erosion, contributes biologically fixed nitrogen and provides alternate hosts for beneficial enemies of crop pests) and (d) Hedgerows and buffer vegetation: trees or shrubs around the perimeter of fields can have many useful functions (provide protection from wind, exclude or enclose animals and produce an array of tree products). 
With reference to this last point, according to Böller et al. [38], the ecological infrastructure network is composed by three fundamental elements: large areas for permanent fauna habitats, smaller habitats that allow the accumulation of temporary animal populations and green corridor infrastructures that help animal species move between large and mediumsized habitats. It is estimated that the optimal area dimension of ecological infrastructure in a productive site to ensure adequate diversity of species is close to $15 \%$ [38]. According to the International Organization for Biological and Integrated Control (IOBC), a minimum of $5 \%$ in the agricultural land must be used for ecological infrastructure [39].

With this goal, following the guidelines of the Piedmont region for the adaptation of interventions to the UNESCO sites [36], existing trees and large shrubs were kept, creating a natural green space as a biodiversity hotspot on the perimeter of vineyard. Rows of trees and shrubs were planted along roads and fields' edges, which therefore act as connecting corridors between ecological areas. Areas of linear elements and non-linear elements were put into a system with the aim of generating a diverse and rich landscape in terms of biodiversity.

In Figure 14, we explain with which interventions the four previous actions (intercropping, strip cropping, covercropping and buffer vegetation) could be carried out: natural and seminatural grassland, interspersing hedges with the vines, the provision of compensatory areas, wildflower strips, planting shrubs at the ends of each row and planting trees as a way of improving vertical diversity. The scheme (Figure 14) is deliberately generic because it proposes to be a taxonomy that can be replicated in different wine-growing contexts.

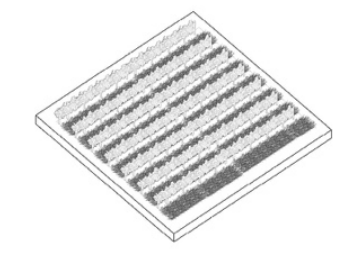

Natural and seminatural grassland

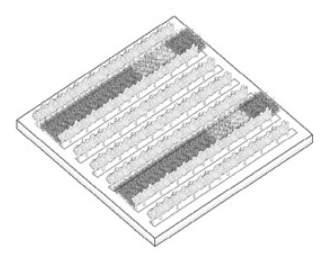

Wildflower strips

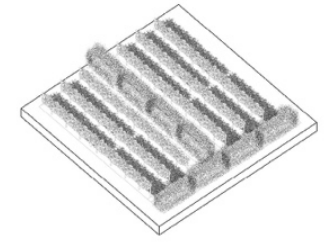

Interspersing hedges with the vines

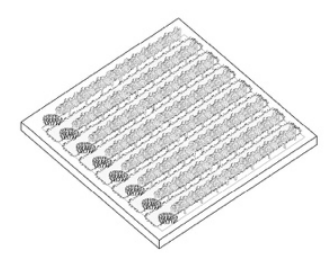

Planting shrubs at the ends of each row

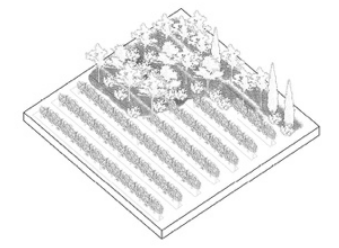

The provision of compensatory areas

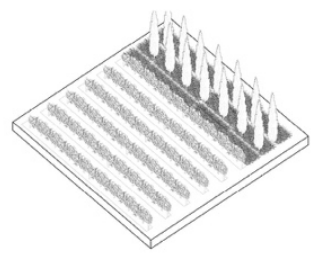

Planting trees as a way of improving vertical diversity

Figure 14. Strategies to improve biodiversity in the vineyard (source: Elaboration by Zhang, Zhang).

Parallel to the ecological infrastructures, a network of slow paths has been imagined. The corridor inside the site can become a possible extension of the external path, equipping it with shaded stops and bicycle parking (following the guidelines of [36]). The corridor is divided into two parts: east and west. On the sloping site, to the west, a system of platforms was created to connect nodes, with inclinations adapted to allow access by cyclists and people with reduced mobility (Figure 15).

The entire rural space was conceived as a public park, integrated with the existing village and ready to host anyone. In particular, the Wine Park is a multifunctional area obtained from the previous parking lot, flexible and suitable for hosting various events (Figures 16 and 17). 


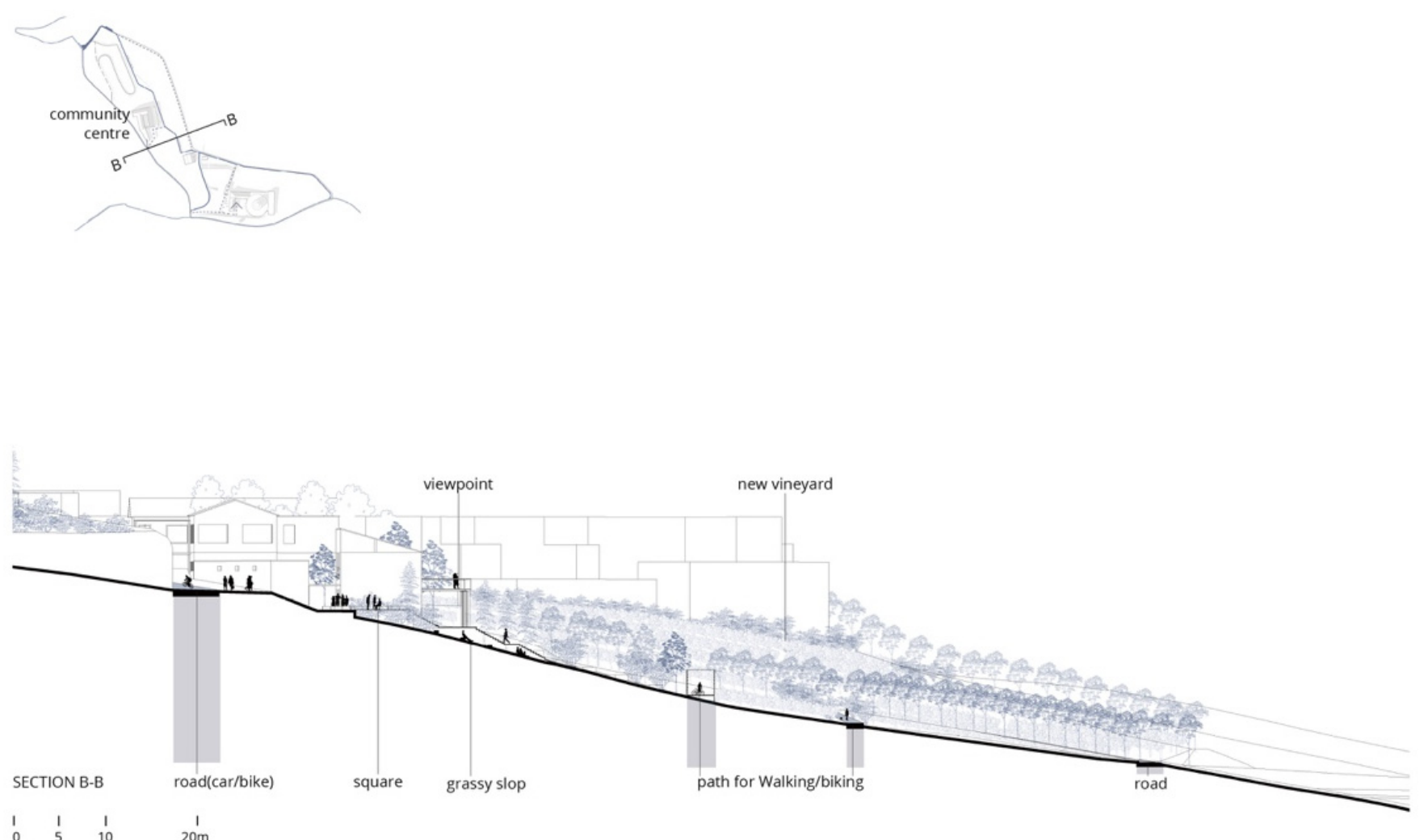

Figure 15. A section of the sloping site, with the system of platforms (source: Elaboration by Zhang, Zhang).

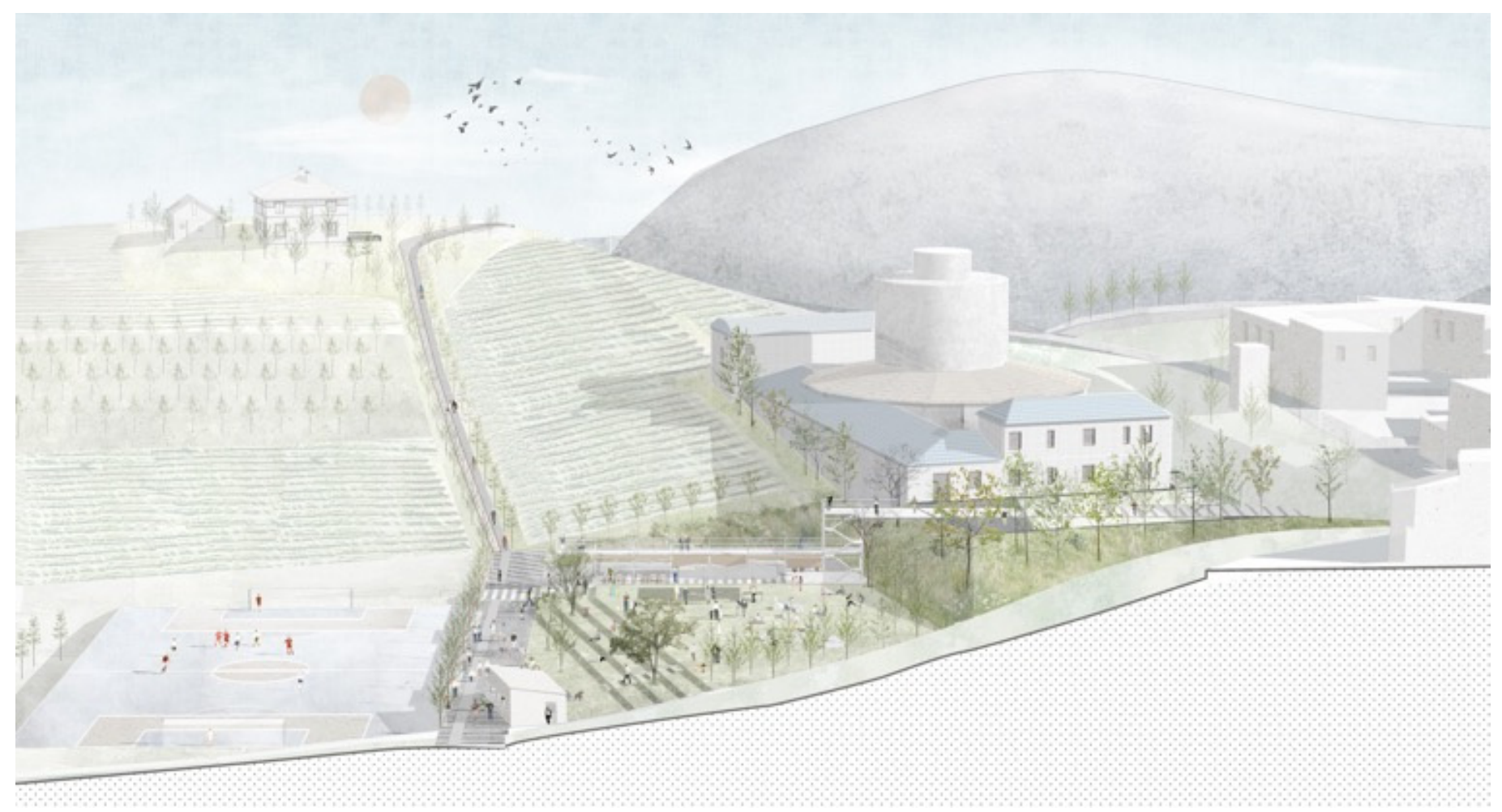

Figure 16. A view of the Wine Park (source: Elaboration by Zhang, Zhang). 


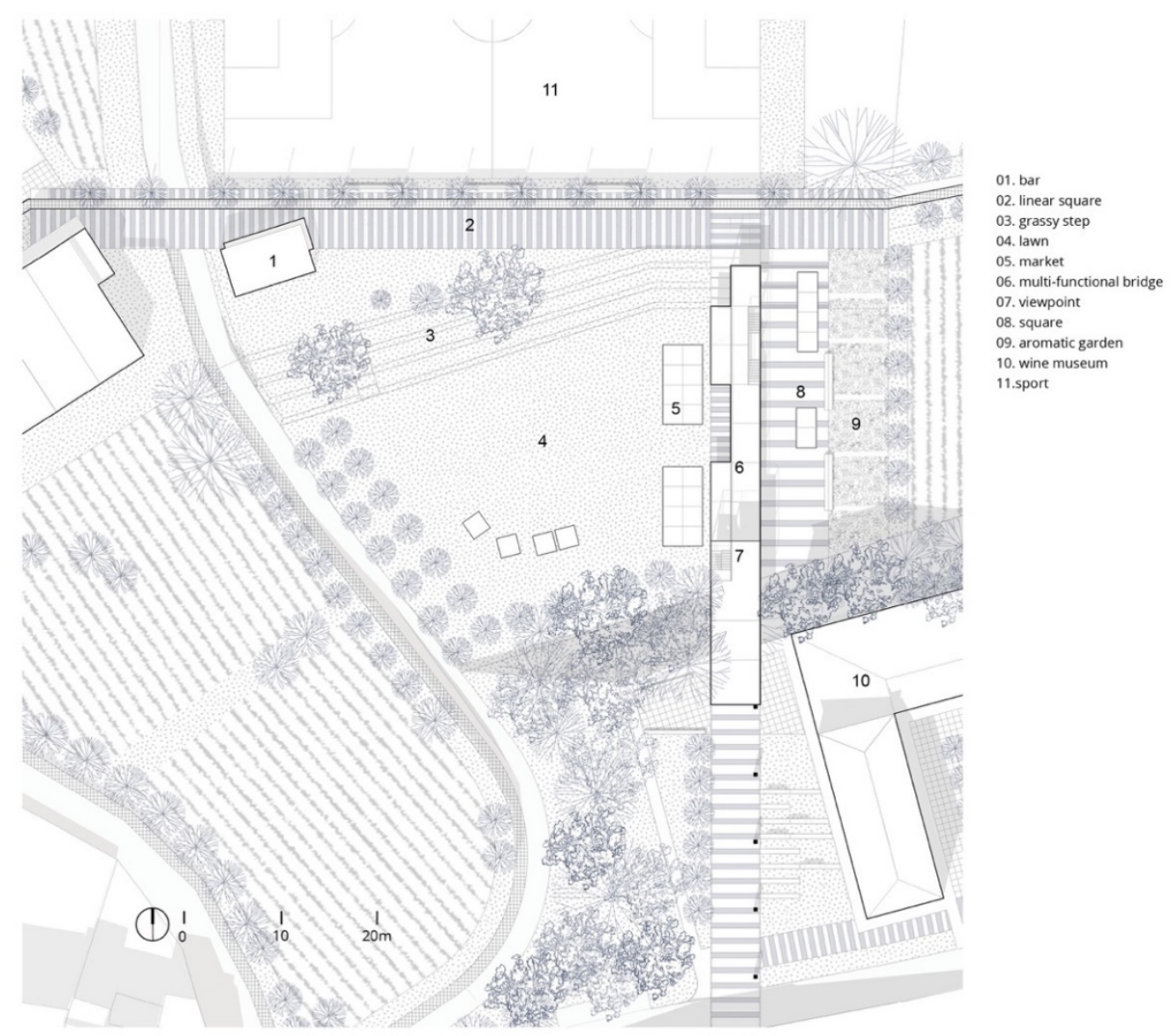

Figure 17. The masterplan of the Wine Park (source: Elaboration by Zhang, Zhang).

The wine school is aimed at people of all ages or educational levels who decide to pursue a career as a winemaker. We propose, here, a schematic hypothesis for the first start of the wine school model, with three types of courses of different duration, from two days to nine months (Figure 18). Among them, only students with a long course duration receive accommodation. The other two types of students can find accommodation in the village (small hotels or Airbnb), which can benefit the local economy. In general, the cost of the courses can vary between 100 euros per person, for those of 1-2 days, to 9100 euros per person, for those of nine months. The proceed from tuition can be used as a stable source of income to help the project sustain itself. In the short term, the goal is to provide jobs for the locals through the school, museum and other activities. We estimate that the project can bring 8/10 jobs to residents, including teaching and service (Figure 19). The long-term goal is to attract students interested in wine production. A total of 30-36 students can be accommodated (Figure 20). 
Long-term Training

\begin{tabular}{l} 
Who \\
To provide land, resources and \\
professional guidance to young \\
people who want to work in the \\
vineyard and related industries. \\
Objective \\
Supporting the training and \\
development of new farmers \\
through real farm experience \\
and nurturing a new generation \\
of young farmers. \\
Duration \\
9 months \\
Provided \\
Workshops and farm tours \\
- Land use \\
One-on-one instruction by \\
experienced farmers \\
On-site grape growing, including \\
pest and disease management, \\
fertilization and pruning \\
Farm management and operation \\
Learning winemaking techniques \\
- Eventually sell your own produce \\
\hline
\end{tabular}

Including accommodation
Short Courses

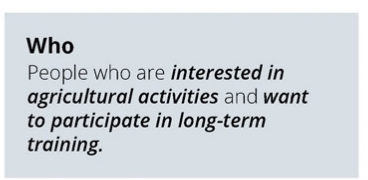

\section{Objective}

Provide specialized agricultural knowledge courses and prepare

for participation in long-term courses.

\begin{tabular}{|l|c|}
\hline $\begin{array}{l}\text { Duration } \\
1 \text { week }\end{array}$ & Price \\
\hline
\end{tabular}

Provided
Grape growing techniques
workshop
- Farm Tour
- Experience viticulture in the field
- Experience the winemaking
process

No accommodation

\section{Agricultural Education Activities}

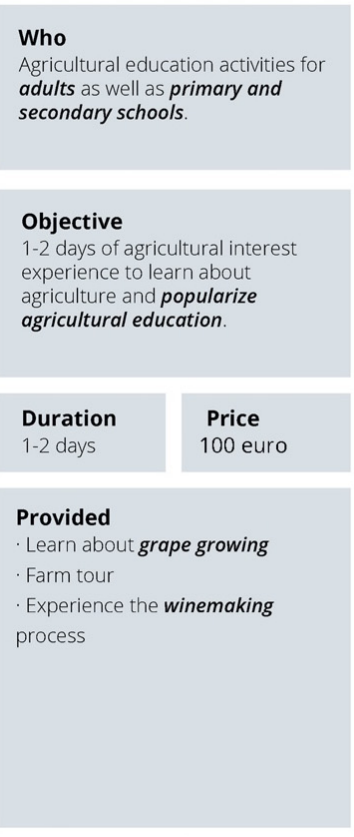

No accommodation

Figure 18. A diagram showing the school's courses (source: Elaboration by Zhang, Zhang).

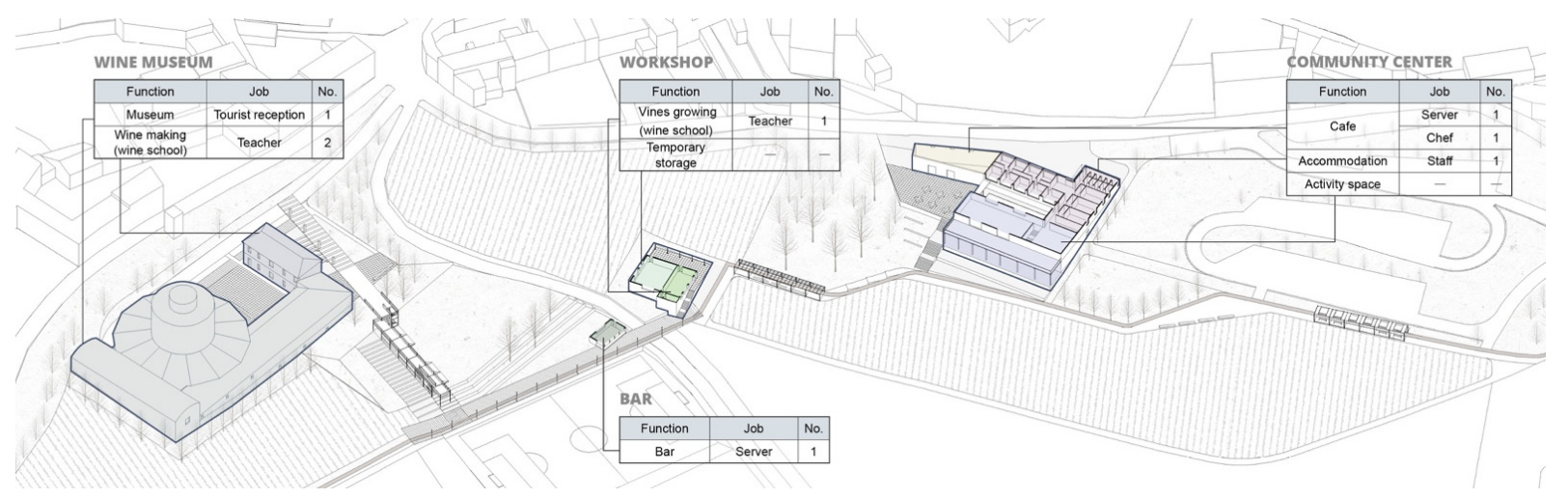

Figure 19. A design diagram showing the number of jobs generated (source: Elaboration by Zhang, Zhang).

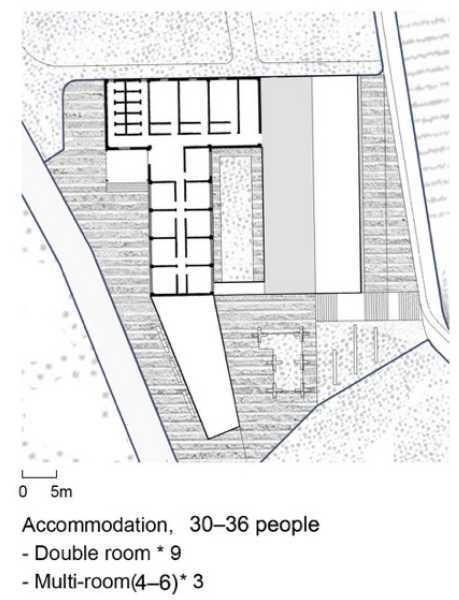

Figure 20. A simple diagram showing the maximum number of people allowed for accommodation (source: Elaboration by Zhang, Zhang). 


\section{Discussion}

The following work explored the landscape design potential in improving resilience of a rural area. Aspects of strengthening resilience concern both the agri-environmental system and socio-economic point of view. The concept of diversity is the foundation of an agroecological project that strengthens resilience, both from an ecological point of view (incorporating many of the components of ecosystem function that are important in nature) and from a managerial point of view (agricultural multifunctionality allows support of quality production) [37]. Meeting this challenge means determining the relationships between the different kinds of diversity and the resilience of the system.

In undertaking the work, two integrated paths have been developed: the masterplan of an innovative agriculture, which becomes a place of education but also a public space integrated into the existing system (Figures 21 and 22), and the model of a multifunctional agriculture, oriented towards teaching and tourism (Figures 18-20). This model does not want to deny the original productive identity of agriculture but to track down additional possibilities for maintaining the rural vocation, acting as an attractor for revitalization and rural enhancement of the territory.

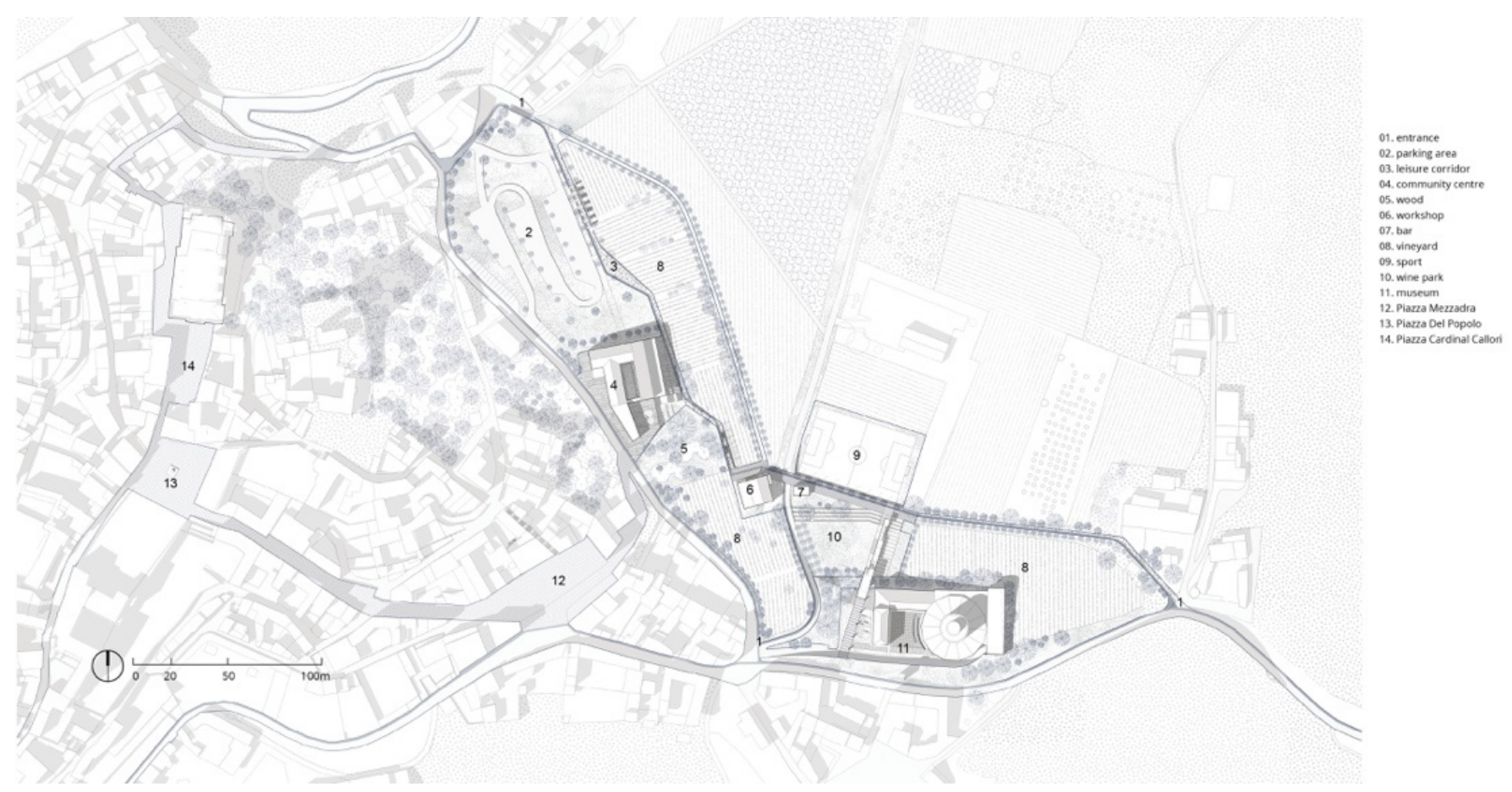

Figure 21. The masterplan proposed (source: Elaboration by Zhang, Zhang).

The project takes Vignale Monferrato as an application case, converting 3.7 hectares of unused land into a multifunctional farm, with a wine school, a museum of wine culture and leisure spaces open to local community.

Regenerating an abandoned territory can contribute to the values of integrity and authenticity required by the World Heritage List, especially if the restoration concerns precisely the wine vocation.

The integrity and authenticity of the UNESCO property are ensured by the different planning tools that structured the proposed interventions: Regional Landscape Plan [24], Law 378 of 24/12/2003 on the Protection and Enhancement of Rural Architecture [33], the Landscape Report of the dpcm 12/12/2005 [34], the Criteria and Guidelines for the Landscape Protection [35], the Management Plan of the property [26] and, especially, the Guidelines for the Adaptation of Regulatory Plans and Building Regulations to the protection indications for the UNESCO sites of the Piedmont Region [36]. According to these instruments, the interventions relating to the Buffer Zones bordering the Core Zones 
must necessarily, on one hand, guarantee the integrity of the site and, on the other, favor the recovery of viticulture and abandoned buildings, the preparation of educational activities and access paths to the Core Zone and provide catering services and bike parking.

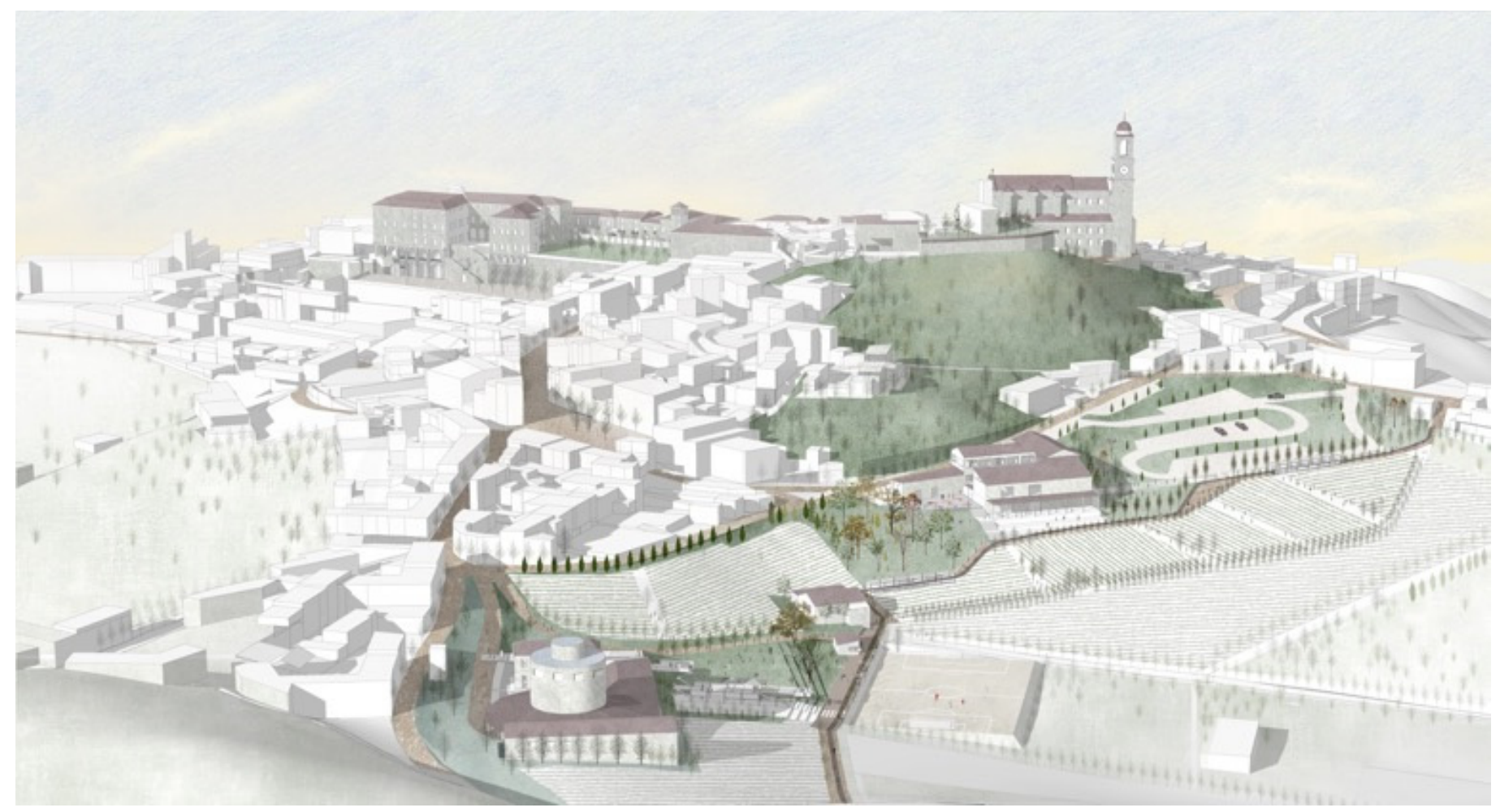

Figure 22. A view of the masterplan proposed (source: Elaboration by Zhang, Zhang).

In this sense, we can affirm that not only the UNESCO property would not be altered, but the actions pursued would also help to curb the depopulation of the site: new jobs and new micro-economies that enhance local identities can contribute to a slow rebirth of fragile territories [18]. The model could provide eight new jobs, and the wine school could accommodate up to 36 students in long-term courses. At the start of the project, tuition fees for education courses are used as a source of income. As other functions are improved, the tourism brand is established and attracts more tourists. The new revenues can be invested in the conservation of the cultural heritage.

The rural villages' revitalization and the heritage's conservation are universal issues that affect all rural systems in the world, which is why the aim of this study was to find measures that could be replicated in other territories. From the planning point of view, it is possible to draw many aspects of replicability, concerning the enhancement and reuse of local resources; the network of open spaces, as the rural space has the possibility of being a public space; the infrastructure of slow paths, which can generate local and supra-local systems and green networks integrated into the productive landscape, which can increase biodiversity and restore the original historical image of rural areas.

If the model develops successfully, it can achieve the stability and continuity of the cultural landscape over time.

The design process has produced a master's thesis that will be presented to the local municipality as a simulation of a possible project.

From the didactic point of view, the design process has provided the possible tools for students to take control of the objectives, to assume the direction of learning and to understand the meaning it can have in a larger collective system that is society.

In the didactic path we have described in the previous paragraphs, the design process is linked to a dynamic and constantly evolving relationship between the individual and 
the collective, where the collective is a multiple subject: it is the work group; it is the relationship between professor and student, which can become a team (like in this case) and it is also the community of the place that we want to regenerate. In the didactic practice, working with places and communities that inhabit them means transmitting not only knowledge and how to build it, but also the effects it can product.

\section{Conclusions}

The problem of depopulation of rural systems on a global scale puts at risk the varied and rich rural heritage and the environmental systems that host it $[16,17]$. In this heritage at risk, we can find one of the cornerstones of the territorial rebirth of many rural villages. In this sense, we see the abandonment as not a final state, but as an intrinsic opportunity for a second beginning [40].

Coherent to this concept, the main objective for European cohesion policies, such as SNAI in Italy [18], is the reversal of the demographic trend of these territories, and it is pursued through two classes of actions: (i) the first focuses on adjusting the offer of essential services, or the preconditions for the territorial development; (ii) the second aims to implement interventions in favor of local development, focused on generating labor demand through the reuse and enhancement of territorial capital. Precisely in this last class of actions, there are tools that solicit the enhancement of resources through quality actions with a low environmental impact.

The different forms of sustainable tourism (slow tourism, green tourism, rural tourism, ecotourism, etc.) can be the appropriate action for this type of strategy [29,41,42].

Today, farms are changing towards new forms of business, through the development of activities that add value to products [43]: this means talking about the agricultural multifunctionality of the business [19]. In the OECD definition, multifunctionality is related to the joint presence of both the ability of agriculture to produce food goods as well as secondary goods and services, thus carrying out social, cultural and environmental functions, as well as a productive one [19].

Therefore, the protection and regeneration of cultural and fragile landscapes should be an intentional orientation of policies, but it can be implemented thanks to a landscape project intervention, which keeps productivity active through a multifunctional vision of agriculture.

In this context, the didactic process was useful to understand how a pioneering vision could be implemented thanks to an exploratory investigation and a research process, which takes the form of a cognitive act also in its design development (research-by-design). Once again, it is a question of multidisciplinarity, experimentation, skills and horizontality of local governance.

It is with these assumptions, which deconstruct rhetorical premises and orient different knowledge to a single project understood as a research process, that the intervention in the rural landscape can be a catalyst of biunivocal dynamics between conservation and innovation.

Author Contributions: Conceptualization, C.D.; methodology, C.D.; data collection, C.Z., Y.Z.; data curation, C.D., C.Z., Y.Z.; writing-original draft preparation, C.D.; writing-review and editing, C.D.; supervision, C.D., D.M. was involved in consolidating the point of view regarding resilience of cultural rural landscapes across the entire paper. C.Z. and Y.Z. produced all the images and maps. All authors have read and agreed to the published version of the manuscript.

Funding: This research received no external funding.

Institutional Review Board Statement: Not applicable.

Informed Consent Statement: Not applicable.

Data Availability Statement: Not applicable.

Acknowledgments: The authors would thank the colleagues Mario Paris (Polytechnic of Milan), Francesca Vigotti (Polytechnic of Milan) and Cristina Sciarrone (Superintendence of Archeology, Fine 
Arts and Landscape). We also thank the four reviewers of the editorial process for helpful suggestions that greatly improved the paper.

Conflicts of Interest: The authors declare no conflict of interest.

\section{References}

1. World Heritage Convention. 1992. Available online: https:/ / whc.unesco.org/en/convention/ (accessed on 26 July 2021).

2. Salter, C. The Cultural Landscape; Duxbury Press: Pacific Grove, CA, USA, 1971.

3. Piccardi, S. Il Paesaggio Culturale; Patron Editore: Bologna, Italy, 1986.

4. Piccardi, S. Il Paesaggio Culturale in Geografia; Patron Editore: Bologna, Italy, 1987.

5. Andreotti, G. Paesaggi Culturali. Teoria e Casi Studio; Unicopli: Milano, Italy, 1996.

6. Andreotti, G. Alle Origini del Paesaggio Culturale. Aspetti di Filologia e Genealogia del Paesaggio; Unicopli: Milano, Italy, 1998.

7. Barbera, G.; Biasi, R.; Marino, D. I Paesaggi Agrari Tradizionali. Un Percorso per la Conoscenza; FrancoAngeli: Milano, Italy, 2014.

8. Dezio, C. Paesaggi agrari resilienti. Approcci e Metodi per L'analisi di Pratiche Processi e Strategie Territoriali; FrancoAngeli: Milano, Italy, 2020.

9. Gulinck, H.; Wagendorp, T. References for fragmentation analysis of the rural matrix in Cultural Landscapes. Landsc. Urban Plan. 2002, 58, 137-146. [CrossRef]

10. Palang, H.; Alumae, H.; Antrop, M.; Helmfrid, S. Rural Landscapes: Past processes and future strategies. Landsc. Urban Plan. 2005, 70, 3-8. [CrossRef]

11. Rescia, A.; Willaarts, B.; Schmitz, M.; Aguilera, P. Changes in land uses and management in two nature reserves in Spain: Evaluating the social-ecological resilience of cultural landscapes. Landsc. Urban Plan. 2010, 98, 26-35. [CrossRef]

12. Solymosi, K. Indicators for the identification of cultural landscape hotspots in Europe. Landsc. Res. 2011, 36, 3-18. [CrossRef]

13. Dezio, C.; Cavallo, A.; Marino, D. Resilient agrarian landscapes in face of changes: The coevolutive approach to understand the links between communities and environmental characters. In Biocultural Diversity in Europe; Agnoletti, M., Emanueli, F., Eds.; Springer: Berlin/Heidelberg, Germany, 2016.

14. Dezio, C.; Marino, D. A reading model for Resilience in Terraced Wine Landscape. In Terraced Landscapes: Choosing the Future; Alberti, F., Dal Pozzo, A., Murtas, D., Salas, M.A., Tillmann, T., Eds.; Regione del Veneto, Direzione Pianificazione Territoriale, Strategica e Cartografia: Venezia, Italy, 2018.

15. Plieninger, T.; Bieling, C. Resilience and the Cultural Landscape-Understanding and Managing Change in Human-Shaped Enviornments; Cambridge University Press: Cambridge, UK, 2012.

16. Rey Benayas, J.M.; Martins, A.; Nicolau, J.M.; Schulz, J.J. Abandonment of agricultural land: An overview of drivers and consequences. CAB Rev. Perspect. Agric. Vet. Sci. Nutr. Nat. Resour. 2007, 2, 14. [CrossRef]

17. De Rossi, A. Riabitare l'Italia. Le Aree Interne Tra Abbandoni e Riconquiste; Donzelli Editore: Roma, Italy, 2018.

18. SNAI. Strategia Nazionale per le Aree Interne. Available online: https://www.agenziacoesione.gov.it/strategia-nazionale-areeinterne/ (accessed on 15 October 2021).

19. OECD. Multifunctionality: Towards an Analytical Framework; OECD Publishing: Paris, France, 2001. [CrossRef]

20. Zhang, C.; Zhang, Y. Design with Landscape. An Experimental Model towards a Goal of Resilience in Vignale Monferrato. Master's Thesis, Politecnico di Milano, Milan, Italy, 23 July 2021.

21. Roggema, R. Research-by-design: Proposition for a methodological approach. Urban Sci. 2017, 1, 2. [CrossRef]

22. Frankel, L.; Racine, M. The complex field of research: For design, through design, and about design. In Proceedings of the Design and Complexity_DRS International Conference, Montreal, QC, Canada, 7-9 July 2010. Available online: https: //dl.designresearchsociety.org/drs-conference-papers/drs2010/researchpapers/ 43 (accessed on 15 October 2021).

23. Common Agricultural Policy. Available online: https://ec.europa.eu/info/food-farming-fisheries/key-policies/commonagricultural-policy_en (accessed on 26 July 2021).

24. Regional Landscape Plan of Piedmont. Available online: https://www.regione.piemonte.it/web/temi/ambiente-territorio/ paesaggio/piano-paesaggistico-regionale-ppr (accessed on 15 October 2021).

25. Langhe-Roero Monferrato UNESCO. Available online: https://whc.unesco.org/en/list/1390/ (accessed on 26 July 2021).

26. UNESCO World Heritage. List The Vineyard Landscape of Piedmont: Langhe-Roero and Monferrato; Nomination Book; UNESCO: Paris, Italy, 2014.

27. ISTAT Data. Available online: https:/ / www.istat.it (accessed on 26 July 2021).

28. Comoli, V.; Lusso, E. Monferrato. Identità di un Territorio; Cassa di Risparmio di Alessandria: Alessandria, Italy, 2005.

29. Dezio, C. Agritourisms and slow lines: Hybrid practices for a landscape design model to support agriculture of mountain regions. The Vermont case reading from Italian perspective. Ciudades 2021, 24, 79-98.

30. VENTO Project. Available online: http://www.cicloviavento.it (accessed on 26 July 2021).

31. Pileri, P.; Giacomel, A.; Giudici, D. VENTO. La Rivoluzione Leggera a Colpi di Pedale e Paesaggio; Corraini Edizioni: Mantova, Italy, 2015.

32. Agudelo Winther, E.; Overton, M.; Heron, C. The Farm Incubator Toolkit: Growing the Next Generation of Farmers. Developed by the National Incubator Farm Training Initiative (NIFTI); The New Entry Sustainable Farming Project: Lowell, MA, USA, 2013. Available online: https:/ / nesfp.org/sites/default/files/uploads/nifti_toolkit_v2.pdf (accessed on 16 July 2021). 
33. Legge 378 del 24/12/2003 sulla Tutela e Valorizzazione dell'Architettura Rurale. Available online: https://www.camera.it/ parlam/leggi/033781.htm (accessed on 15 October 2021).

34. Di Bene, A.; Scazzosi, L. La Relazione Paesaggistica. Finalità e Contenuti. Decreto del Presidente del Consiglio dei Ministri, 12 Dicembre 2005; Gangemi Editore: Roma, Italy, 2006.

35. Regione Piemonte Assessorato ai Beni Ambientali Direzione Pianificazione e Gestione Urbanistica Settore Gestione Beni Ambientali Criteri e Indirizzi per la Tutela del Paesaggio. Available online: https://www.regione.piemonte.it/web/temi/ambienteterritorio/paesaggio/normativa-paesaggio (accessed on 15 October 2021).

36. Regione Piemonte Sito UNESCO I Paesaggi Vitivinicoli del Piemonte: Langhe-Roero e Monferrato. Linee Guida per L'adeguamento dei Piani Regolatori e dei Regolamenti Edilizi Alle Indicazioni di Tutela per il Sito UNESCO. Available online: https:/ / www.regione.piemonte.it/web/temi/ambiente-territorio/paesaggio/sito-unesco-dei-paesaggi-vitivinicoli-piemontemisure-strumenti-tutela (accessed on 15 October 2021).

37. Gliessman, S.R. Agroecology. The Ecology of Sustainable Food Systems; CRC Press Taylor\&Francis Group: Boca Raton, FL, USA, 2015.

38. Boller, E.F.; Haäni, F.; Poehling, H.M. Ecological Infrastructures. Ideabook on Functional Biodiversity at the Farm Level; IOBCwprs Commission on Integrated Production Guidelines and Endorsement: Zurich, Switzerland, 2004.

39. Stefanucci, S.; Graça, A.; Novello, V.; Belda, I.; Carlos, C.; Gautier, J. Oiv Collective Expertise Functional Biodiversity in The Vineyard. 2018. Available online: https://www.oiv.int/public/medias/6367/functional-biodiversity-in-the-vineyard-oivexpertise-docume.pdf (accessed on 26 July 2021).

40. Dezio, C. Abandonment Territorial Fragilities in Territorial Fragilities in Italy. Defining a Common Lexicon. Territorio 2020, 91, 25-26.

41. Dezio, C. A bioregional reading of the rural landscapes of the Italian inner areas and the regenerative potential of rural tourism. The case study of the VENTO project. Ciudades 2020, 23, 46-69. [CrossRef]

42. Pileri, P.; Moscarelli, R. Cycling \& Walking for Regional Development. How Slowness Regenerates Marginal Areas; Springer: Berlin/Heidelberg, Germany, 2021.

43. ISMEA. Strategie di Marketing per L'azienda Agrituristica: Linee Guida per la Vendita Diretta dei Prodotti; ISMEA: Roma, Italy, 2016. 